\title{
The Impact of Matrix Metalloproteinase-9 on the Sequential Steps of the Metastatic Process
}

\author{
Giovanni Barillari
}

Department of Clinical Sciences and Translational Medicine, University of Rome Tor Vergata, 1 via Montpellier, 00133 Rome, Italy; barillar@uniroma2.it; Tel.: +39-06-7259-6510

Received: 31 May 2020; Accepted: 23 June 2020; Published: 25 June 2020

\begin{abstract}
In industrialized countries, cancer is the second leading cause of death after cardiovascular disease. Most cancer patients die because of metastases, which consist of the self-transplantation of malignant cells in anatomical sites other than the one from where the tumor arose. Disseminated cancer cells retain the phenotypic features of the primary tumor, and display very poor differentiation indices and functional regulation. Upon arrival at the target organ, they replace preexisting, normal cells, thereby permanently compromising the patient's health; the metastasis can, in turn, metastasize. The spread of cancer cells implies the degradation of the extracellular matrix by a variety of enzymes, among which the matrix metalloproteinase (MMP)-9 is particularly effective. This article reviews the available published literature concerning the important role that MMP-9 has in the metastatic process. Additionally, information is provided on therapeutic approaches aimed at counteracting, or even preventing, the development of metastasis via the use of MMP-9 antagonists.
\end{abstract}

Keywords: AKT; cancer; EMT; HIV-protease inhibitors; integrins; metastasis; MMP-9; tumor cell invasion

\section{Introduction}

In malignant tumors, transformed cells replicate continuously and infiltrate the tissue from which they originated, replacing preexisting normal cells [1]. Later, proliferating malignant cells eventually diffuse to adjacent and/or distant tissues and organs, giving rise to secondary tumors, i.e., metastases [1]. The latter maintain the phenotypic features of the primary tumor, hence completely upsetting the homeostasis of the human body and rendering the tumor incurable [1].

Cancer metastases occur in sequential steps; in other words, malignant cells: (a) detach from the primary tumor mass; (b) digest the surrounding extracellular matrix (ECM) and migrate through it; (c) penetrate local blood or lymphatic vessels (intravasation), and are transported by the blood or lymph throughout the organism; (d) arrest in the narrow lumen of small vessels, breach the vessel wall, and transmigrate into the extravascular space (extravasation); (e) adapt to the new anatomic site and outgrow [1].

All these steps require cancer cells to break down ECM structures, i.e., the interstitial matrix, which fills the space between the cells of a given tissue, and the basement membranes, sheets of ECM that separate cells lining the epithelium or endothelium from the underlying connective tissue [1,2]. The interstitial matrix is composed of proteoglycans, fibrillar collagens and noncollagenous glycoproteins that are mainly synthesized by stromal cells [2]. Basement membranes are constituted of molecules such as collagen IV, laminin, elastin, fibronectin and tenascin, which are made by epithelial, endothelial or stromal cells [2]. The ECM binds a significant share of cellular products, including growth factors or inflammatory mediators, and stores them in a biologically active form which is preserved from degradation otherwise occurring via serum or tissue protease activity [2]. During cancer cell invasion and metastasis, tumor cells digest the ECM molecules by synthesizing and employing a large 
variety of enzymes; among them, the matrix metalloproteinases (MMPs) are the main contributors to ECM degradation by tumor cells [3].

MMPs represent a family of proteases which display a common structure consisting of an amino-terminal propeptide domain, a zinc-containing catalytic site, a hemopexin domain granting substrate specificity, and a hinge region which links together the catalytic and hemopexin domains, thereby endowing flexibility upon the enzymatic molecule [4].

The majority of MMPs are released by the producing cells in the extracellular compartment, and other MMPs are bound to the cell membrane. Altogether, these enzymes proteolytically cleave ECM molecules in a redundant fashion [3,4]. Specifically, among released MMPs, stromelysins (MMP-3, MMP-7, MMP-10 and MMP-11) break down most of the ECM components, while interstitial collagenases (MMP-1, MMP-8 and MMP-13) digest collagen I, II and III in close proximity to cells [3,4]. Still regarding released MMPs, the MMP-12 cleaves elastin or fibronectin, and gelatinases (MMP-2 and MMP-9) digest either basement membrane components, such as laminin and collagen IV, or interstitial collagen fragments [3,4]. For their part, the six types of cell surface-bound MMPs, termed membrane-type (MT)-MMPs, can process both released MMPs and ECM molecules [5].

During embryonic life, MMPs are constitutively produced, being important to organ morphogenesis $[4,5]$; in adult tissues, MMPs are expressed at very low to undetectable levels, being upregulated only during physiological tissue remodeling or in reactive processes, such as inflammation and wound repair $[4,5]$. In these conditions, the extent and duration of MMP activity is tightly regulated by endogenous inhibitors including serum antiproteases and the Tissue Inhibitors of MMPs (TIMPs) [6]. Specifically, in humans, four types of TIMPs are known, each of which hampers the function of multiple MMPs by binding to their catalytic and/or hemopexin domain [6].

In chronic inflammatory or degenerative diseases, MMPs are overexpressed, altering the TIMP/MMP ratio and leading to a considerable increase in MMP activity $[3,7]$.

Similarly, high MMP levels are found in many types of human cancers, positively correlating with their clinical progression [8-10]. Consequently, MMPs are considered as either tumor markers or antitumor therapeutic targets $[9,10]$.

Among MMPs, MMP-9 (also termed gelatinase B) exerts a variety of activities, most of which favor tumor growth and spread [10,11]. However, MMP-9 can also have antitumor effects; this dual behavior depends on the cancer type and/or clinical stage [12,13].

The role that MMP-9 has in the development of the primary tumor has been described elsewhere [14-16]. Herein, the available scientific literature concerning the impact that the deregulated expression or activity of MMP-9 might exert on solid tumor metastases is reviewed in the context of a Special Issue of the International Journal of Molecular Sciences, entitled "Tumor Cell Invasion and Metastases".

\section{MMP-9 Production or Activity is Regulated at Multiple Levels}

The important role that MMP-9 plays in reactive processes including inflammation and wound repair explains why the enzyme is constitutively expressed only by a few cell types, such as neutrophils and macrophages $[4,17]$. Other cells (including fibroblasts, osteoblasts and epithelial, endothelial, dendritic and T cells) produce MMP-9 primarily upon stimulation with inflammatory cytokines, chemokines, or growth factors [18-24]. Among the inducers of MMP-9 expression are interleukin-1, tumor necrosis factor $\alpha$, epidermal growth factor, transforming growth factor $\beta 1$, vascular endothelial growth factor (VEGF) and the CXC chemokine ligand 12 (CXCL12) (Figure 1) [18-24].

Active MMP-9 can directly degrade laminin and, in concert with other enzymes, collagen IV and $\mathrm{V}$, thereby disrupting the basement membrane $[4,25,26]$. In this context, it should be stressed that similarly to MMP-2, but in contrast with the other members of the family, MMP-9 has a specific collagen-binding domain in its catalytic site $[4,25,26]$. Through this domain, the enzyme binds and further cleaves the soluble monomers of interstitial collagens which result from ECM degradation started by MMP-1, MMP-8 or MMP-13 [2,3,18]. MMP-9 is also capable of directly digesting elastin, 
fibronectin or proteoglycans, which contributes to the dissolution of the interstitial matrix [27-29]. In addition, MMP-9 cleaves and modifies a variety of non-ECM components, such as chemokines, cytokine receptors, growth factors and intercellular adhesion molecules [30-33].

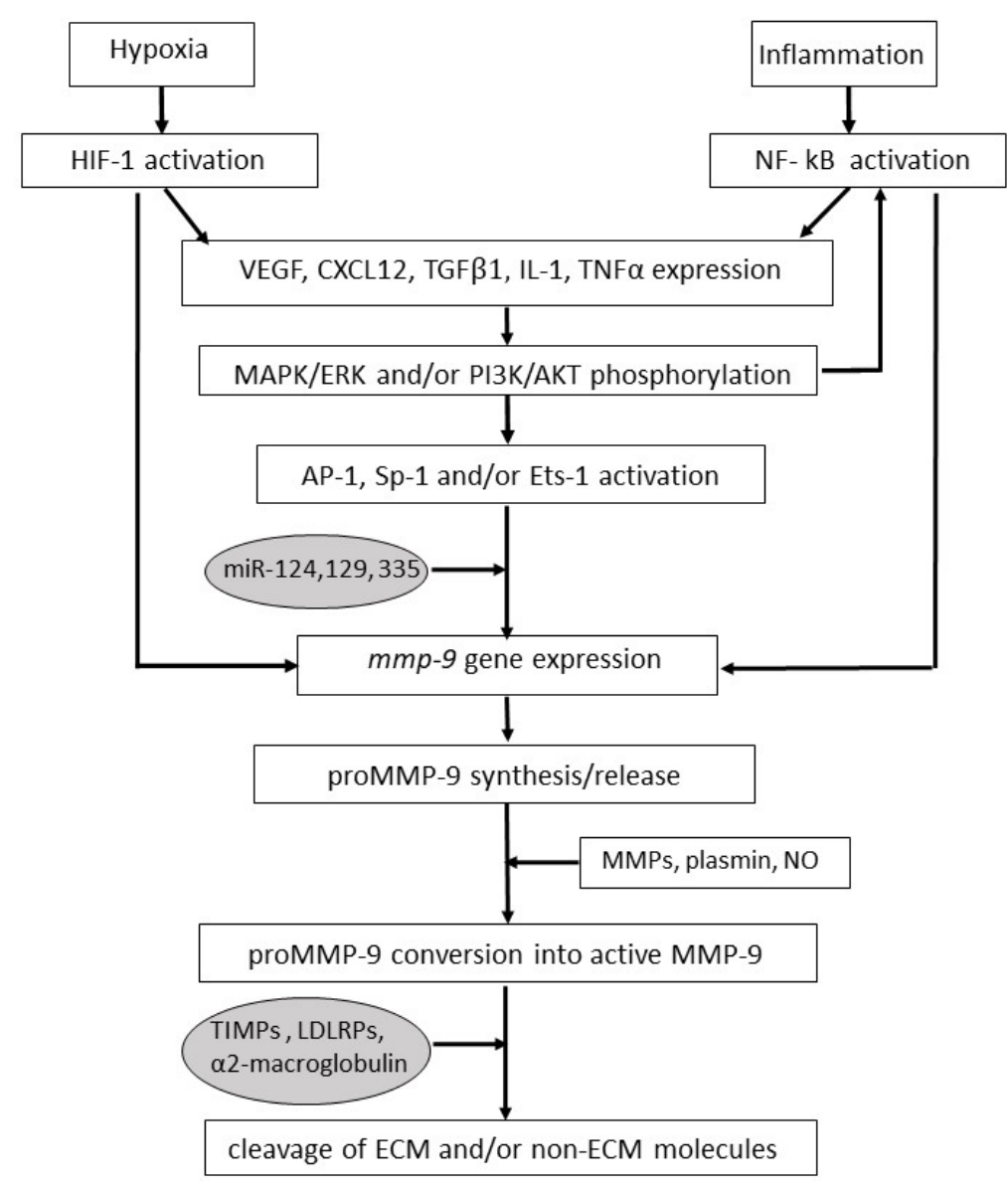

Figure 1. The MMP-9 pathway. In the rectangles, the main molecules and signaling pathways leading to MMP-9 expression or activation are shown; in the ellipses, the endogenous MMP-9 antagonists are listed. Arrows symbolize directions of connections. Abbreviations: AKT, protein kinase B; AP, activator protein; CXCL, CXC chemokine ligand; ECM, extracellular matrix; ERK, extracellular-signal-regulated kinase; HIF, hypoxia-inducible factor; IL, interleukin; LDLRP, low-density lipoprotein receptor-related protein; MAPK, mitogen-activated protein kinase; miR, microRNA; MMP, matrix metalloproteinase; NF-kB, nuclear factor-kappa B; NO, nitric oxide; PI3K, phosphoinositide 3 kinase; Sp, specificity protein; TGF, transforming growth factor; TIMP, tissue inhibitor of matrix metalloproteinase; TNF, tumor necrosis factor; VEGF, vascular endothelial growth factor.

The wide spectrum of MMP-9 substrates enables the enzyme to influence several biological processes $[4,7,12,13,18,23,30-33]$. For this reason, MMP-9 production and activity are tightly regulated at the transcriptional, posttranscriptional, translational and posttranslational levels, as well as by endogenous serum or tissue inhibitors.

Regarding the MMP-9 gene expression, the promoter region of $m m p-9$ gene contains response elements for transcription factors including Activator Protein-1, Specificity protein-1 and Nuclear Factor-kappa B (NF-kB), as well as Ets-1 binding sites; this renders MMP-9 inducible by either inflammatory mediators or growth factors, as mentioned (Figure 1) [18-24,34-36].

In this context, it is noteworthy that transcription factors promoting MMP-9 expression can be repressed by microRNAs, which keeps MMP-9 levels low, unless otherwise required (Figure 1) [37,38].

The MMP-9 protein displays the MMP common core structure, which is constituted by an amino-terminal propeptide, a zinc-binding catalytic site, a linker region and a carboxyl-terminal 
hemopexin domain [4]. Producing cells secrete MMP-9 as zymogen (proMMP-9), in which the zinc atom present at the catalytic site is bound by a cysteine located in the propeptide domain; this interaction fully inhibits MMP-9 activity, thereby maintaining enzyme latency [4]. Thus, proMMP-9 becomes functionally active only upon the excision of its propeptide; this cleavage is executed by other MMPs (including MMP-1, MMP-2, MMP-3, MMP-7, MMP-10, MMP-13 and MMP-26), or additional enzymes such as plasmin, trypsin, kallicrein, elastases or cathepsins (Figure 1) [4]. Of interest, MMP-9 can also be activated before its release; this occurs at the cell membrane level and is mediated by MT1-MMP and MMP-2 [39].

In the extracellular compartment, MMP-9 protein levels are effectively reduced by low-density lipoprotein receptors-related proteins, which complex MMP-9 and cause its uptake and intracellular degradation by macrophages, fibroblasts, hepatocytes and other cell types (Figure 1) [40,41]. In addition, MMP-9 can be counteracted by endogenous inhibitors including serum $\alpha 2$-macroglobulin or TIMPs (Figure 1) [6,42]. Among the latter, TIMP-1 is particularly effective at inhibiting MMP-9 activity [6]. In this regard, it has to be borne in mind that latent MMP-9 is often released in complex with TIMP-1, with the two proteins being joined at their carboxyl-terminals; when latent MMP-9 is converted into its active form, TIMP-1 is freed, and eventually antagonizes active MMP-9 [6].

Deregulated MMP-9 expression and/or activity causes cellular invasiveness and leads to the growth and clinical progression of a wide variety of human cancers [10,14-16,43-53].

In tumor tissues, the control of MMP-9 production is altered or lost due to several causes.

First, cancer cells overexpress MMP-9. This occurs because of both intrinsic and extrinsic mechanisms; the former refers to the unstable genotype of tumor cells featuring the mutation of proto-oncogenes into oncogenes and their abnormal expression, together with the functional impairment of onco-suppressor genes such as p53 (Figure 2) [54-56]. In particular, oncogenes directly upregulate MMP-9 expression [54,55], while p53 inactivation triggers MMP-9 synthesis via an increase of glycolysis (Figure 2) [56-58].

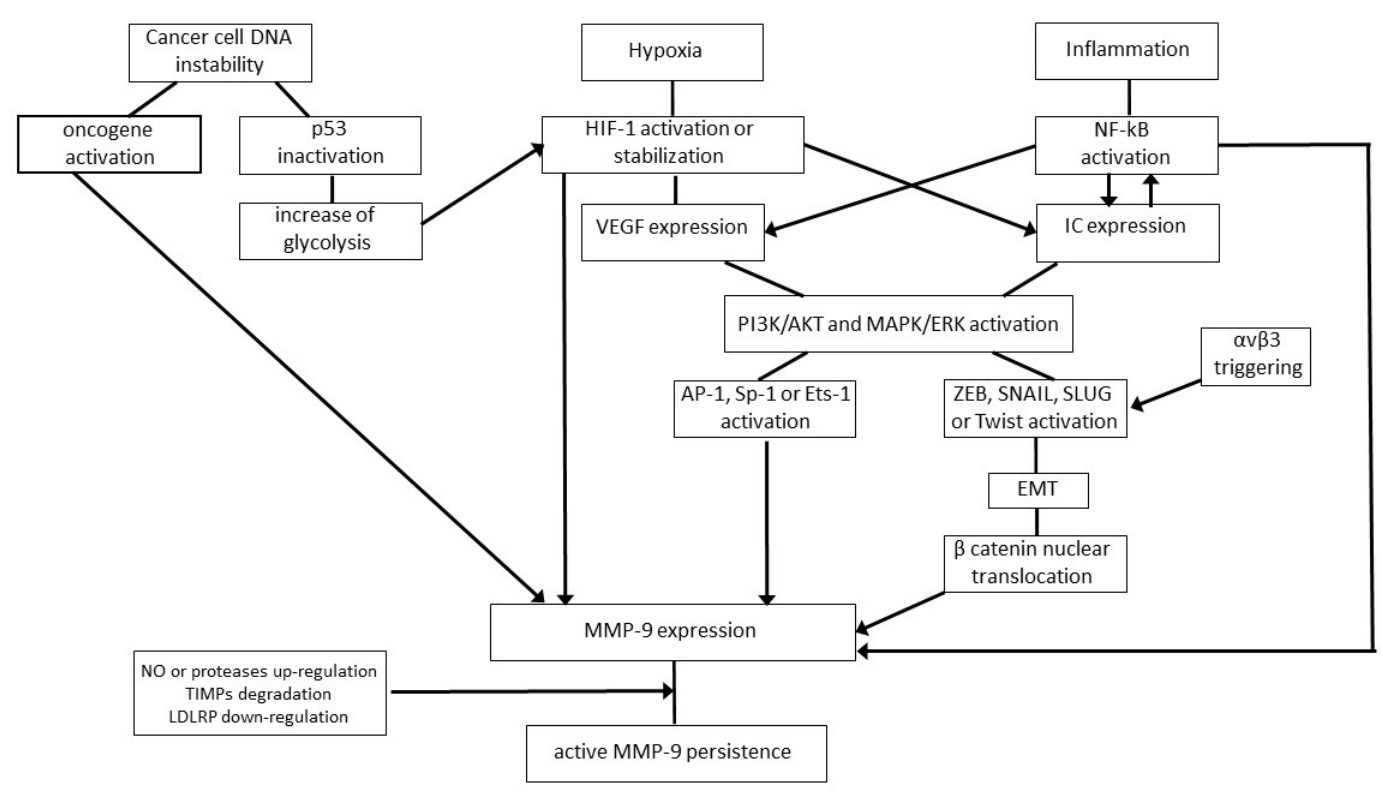

Figure 2. Molecular events promoting the expression and persistence of MMP-9 in tumor tissues. Summary of the molecular pathways leading to MMP-9 overexpression in a wide variety of human tumors. Arrows symbolize directions of connections. Abbreviations: AKT, protein kinase B; AP, activator protein; EMT, epithelial-to-mesenchymal transition; ERK, extracellular-signal-regulated kinase; HIF, hypoxia-inducible factor; IC, inflammatory cytokines; LDLRP, low-density lipoprotein receptor-related protein; MAPK, mitogen-activated protein kinase; MMP, matrix metalloproteinase; NF-kB, nuclear factor-kappa B; NO, nitric oxide; PI3K, phosphoinositide 3 kinase; Sp, specificity protein; TIMP, tissue inhibitor of matrix metalloproteinase; VEGF, vascular endothelial growth factor. 
The extrinsic mechanisms leading to MMP-9 upregulation mainly refer to hypoxia or inflammation, which often coexist at the tumor site (Figure 2) $[59,60]$. Specifically, when the tumor increases in size, the cells placed in its core area become hypoxic, as they are far from the oxygen-supplying blood vessels [59]. Then, a biologically relevant number of hypoxic tumor cells undergo necrosis, and this sets off an inflammatory response in which leukocytes infiltrate the tumor area and produce cytokines such as tumor necrosis factor $\alpha$ and interleukin-1 or -6 (Figure 2) [60]. Under these conditions, intracellular signaling pathways triggering MMP-9 expression, including the phosphoinositide 3 kinase (PI3K)/protein kinase B (AKT) and the mitogen-activated protein kinases (MAPK)/extracellular-signal-regulated kinases (ERK) pathways, are strongly stimulated, as are the MMP-9 transcription factors Activator Protein-1, Specificity protein-1 or Ets-1 (Figure 2) [34,36,57,61,62]. Moreover, NF-kB is further activated by inflammatory cytokines which are its transcriptional targets, thereby promoting MMP-9 expression by both the transformed and normal cells constituting the tumor mass (Figure 2) [62].

It is worthy of note that in some cancer cell types, the microRNAs hampering MMP-9 expression are downregulated, which additionally increases MMP-9 protein levels and cellular invasion [37]. At the same time, tumor hypoxia triggers the hypoxia-inducible transcription factor (HIF)-1, which, in turn, promotes MMP-9 expression either directly or by activating the expression of growth factors, inflammatory cytokines or chemokines which are able to promote MMP-9 expression (Figure 2) [59]. In addition, HIF-1 triggers the production of nitric oxide, a gaseous mediator capable of activating latent MMP-9 by disrupting the bond between the catalytic zinc and the propeptide domain of the enzyme (Figure 2) [63]. Of interest, MMP-9 and nitric oxide synthases frequently colocalize at the leading edge of invading tumor cells [64].

In addition to being produced by the transformed or normal cells composing the tumor mass, MMP-9 is released in a TIMP-1-free form by neutrophils or macrophages which are recruited to the tumor site during the inflammatory response that accompanies cancer development or progression $[4,11,46,60]$. Whatever the source of its production, MMP-9 retrieves ECM-bound, sequestered growth factors into a soluble, highly diffusible form $[65,66]$. The solubilized growth factors, together with inflammatory mediators and additional growth factors released by tumor-infiltrating leukocytes, further stimulate the cells constituting the carcinoma mass to generate additional MMP-9 [11,19-24].

Therefore, at the tumor site, MMP-9 produced by cancer cells combines with that synthesized by normal inflammatory, immune, parenchymal or stromal cells; this leads to a dramatic rise of MMP-9 protein levels which is not paralleled by an increase in TIMP synthesis [11,43-53].

Interestingly, MMP-9 clearance by low-density lipoprotein, receptor-related proteins is reduced in tumors compared to normal tissues (Figure 2) [40]. Furthermore, tumor-infiltrating neutrophils produce enzymes, such as trypsin and chymotrypsin, which degrade local, preexistent TIMPs (Figure 2 and Table 1) [67].

The upregulation of MMP-9 expression and/or activity occurring in tumor tissues has a major role in the realization of the sequential steps of the metastatic process. 
Table 1. Molecules enhancing MMP-9 activity in tumor tissues.

\begin{tabular}{|c|c|}
\hline Molecule & Action \\
\hline Nitric oxide & Contributes to proMMP-9 conversion into active MMP-9 $[63,64]$ \\
\hline Tryspin or chymotrypsin & Degrade TIMPs [67] \\
\hline MMP-2 and MT1-MMP & Activate cell surface-bound MMP-9 [39] \\
\hline Plasmin or MMP-1, 3, 7, 10, 13 and 26 & Activate released MMP-9 [4] \\
\hline$\alpha \mathrm{v} \beta 3$ & $\begin{array}{l}\text { Drives tumor or endothelial cell migration toward chemotactic factors } \\
\text { generated and/or released by MMP-9 [68-71]; Facilitates MMP-9-promoted } \\
\text { cancer cell extravasion [72]; Cooperates with MMP-9 to induce new vessel } \\
\text { formation [73,74] }\end{array}$ \\
\hline$\alpha 4 \beta 1$, CEA or CD24 & Facilitate MMP-9-promoted cancer cell extravasion [75-77]. \\
\hline CD44 & $\begin{array}{l}\text { Facilitates MMP-9-promoted cancer cell extravasion and spatially directs } \\
\text { MMP-9 proteolytic activity [78]. }\end{array}$ \\
\hline CD151 & Facilitates MMP-9-promoted cancer cell locomotion [79]. \\
\hline Neuronal-cadherin & Facilitates the dissemination of cancer cells promoted by MMP-9 [80] \\
\hline VEGF & $\begin{array}{l}\text { Cooperates with MMP-9 to induce cancer cell transendothelial migration } \\
{[81] \text {, and new vessel formation }[73,74,82]}\end{array}$ \\
\hline CXCL12 & Cooperates with MMP-9 in promoting new vessel formation $[73,74,83]$ \\
\hline \multicolumn{2}{|c|}{$\begin{array}{l}\text { List of enzymes (trypsin, chymotrypsin, plasmin, MMPs or MT-MMP), cell surface receptors ( } \alpha \mathrm{v} \beta 3, \alpha 4 \beta 1, \mathrm{CEA}, \mathrm{CD} 24 \text {, } \\
\text { CD44, CD151 or neuronal-cadherin), growth factor (VEGF), chemokine (CXCL12) and the gaseous mediator (nitric } \\
\text { oxide) expressed in cancer tissues, where they enhance the protumor activities of MMP-9. Abbreviations: CD, cluster } \\
\text { of differentiation; CEA, carcinoembryonic antigen; CXCL, CXC chemokine ligand; MMP, matrix metalloproteinase; } \\
\text { MT-MMP, membrane type-matrix metalloproteinase; TIMP, tissue inhibitor of matrix metalloproteinase; VEGF, } \\
\text { vascular endothelial growth factor. References with specific information are shown in square brackets. }\end{array}$} \\
\hline
\end{tabular}

\section{MMP-9 Favors Cancer Cell Detachment from the Primary Tumor by Loosening their Adhesive Interactions and Enhancing their Invasive Capabilities}

The first step of the metastatic process is the dissolution of the intercellular contacts that maintain the mass of the primary tumor [1].

In this regard, it should be remembered that the adhesiveness among cells composing a given tissue is mediated by adherens junctions and, at a lower efficiency level, by tight and gap junctions [84]. In the epithelial tissue, the main actuator of intercellular adhesions is the epithelial-cadherin, a transmembrane glycoprotein that is the core component of epithelial adherens junctions [84-86]. During carcinoma development, growth factors (e.g., epidermal growth factor and transforming growth factor $\beta 1$ ) produced by tumor or normal cells trigger the PI3K/AKT and/or the MAPK/ERK pathway; this leads to the activation of the ZEB1, ZEB2, Snail, Slug or Twist transcription factors which, in turn, induce transformed epithelial cells to acquire a mesenchymal phenotype through a process termed epithelial-to-mesenchymal transition (EMT) (Figure 2) [85,86]. The latter can also be promoted by p53 functional loss accompanying tumor onset [56] or by NF-kB and HIF-1, which are activated by inflammation and low oxygen level, respectively $[87,88]$. EMT endows the transformed cells of the primary tumor with the ability to invade distant tissues $[85,86]$. In fact, EMT ultimately results in the conversion of nonmotile, polarized epithelial cells into highly mobile, myofibroblast-like cells [85,86]. This phenomenon occurs in a limited way during tissue development or repair (where it is quickly followed by a reversion to the polarized, nonmigratory epithelial phenotype), and it is remarkably exacerbated and prolonged over time during cancer progression and metastasis $[85,86]$.

EMT implicates the downregulation or loss of epithelial cell markers, epithelial-cadherin included, and their replacement with mesenchymal cell markers such as neuronal-cadherin $[85,86]$. The cadherin switch is followed by a profound reorganization of the cytoskeleton, implying that epithelial keratins are replaced by mesenchymal vimentin $[85,86]$. Moreover, MMP-2 expression is upregulated, and MMP-9 synthesis is induced [85-90]. In fact, the loss of epithelial-cadherin which occurs during EMT causes the nuclear translocation of $\beta$-catenin, a cytoplasmic protein which is linked to the actin filaments of the cytoskeleton. Once it is in the nucleus, $\beta$-catenin induces NF-kB to activate $m m p-9$ gene expression (Figure 2) [89]. Then, MMP-9 completes the cleavage of interstitial collagens, thereby contributing to cancer cell detachment from the primary tumor mass $[1,3,4,11]$. 
In essence, during the metastatic process, cancer cells change their state from strongly to weakly adherent $[68,85,86]$.

It has to be pointed out that cells are connected to the ECM through so-called integrins, a family of transmembrane receptors which bind ECM components and links them to the cytoskeleton, thereby modulating not only cellular adhesion, but also cell survival, growth, locomotion and differentiation [68]. Integrins are composed of an $\alpha$ subunit, which binds the ligand, and a $\beta$ subunit, that transduces the consequent signaling inside the cell via its connection to the cytoskeleton [68]. The majority of integrins can bind several different ligands, and a specific ECM molecule can be recognized by multiple integrins [68]. Usually, an integrin interacts with one ligand rather than another depending on the conformational state of both the integrin and the ligand [68].

Concerning the topic of the present review, it should be emphasized that the rearrangement of the actin cytoskeleton associated with EMT causes integrins to be internalized $[68,85,86]$. Indeed, MMP-9 could further favor cell detachment because of its ability to shed the integrin $\beta$ subunit from the cell surface [91]. However, most of the anti-adhesive effect of MMP-9 depends on the fact that this enzyme efficiently degrades the pericellular matrix and basement membrane in cooperation with other MMPs and/or additional proteolytic enzymes [11,18,19,27-29].

The breakup of cell-cell or cell-ECM adhesive contacts leads to the invasion of individual cancer cells or multicellular clusters.

Noticeably, many of the matrix-bound growth factors which are released into a soluble form by MMP-9 effectively promote cancer cell locomotion [3,8,11]. Moreover, MMP-9 generates highly chemotactic peptides derived from the degradation of ECM components such as elastin and the collagens [92]. Upon their binding to the integrins, the ECM fragments stimulate not only cellular migration, but also cellular proliferation, thereby strongly contributing to tumor spreading [92].

Tumor cells migrate through cyclical reiterations of frontal elongation and adhesion, followed by cellular constriction and posterior loose $[85,86]$. Specifically, upon the activation of Rho-GTPases promoted by the chemotactic factors, the cytoskeletal actin polymerizes, resulting in the formation of protrusions at the leading edge of migrating cells $[85,86]$. Of note, both the integrins and MMPs concentrate at the cellular protrusions; integrins bind to the ECM which supplies a dais upon which cancer cells move, while MMPs break down the ECM barrier, thereby opening a passage for cancer cell dissemination $[68,85,86]$. Later, the persistent activation of Rho-GTPases triggers cellular constriction and posterior loose, leading to a remarkable frontal elongation of the migrating cancer cells $[85,86]$.

Certainly, tumor cell locomotion depends on somewhat coordinated interaction between integrins and MMPs.

Overall, MMPs bind to integrins through their hemopexin domain, thereby being anchored on the tumor cell surface [68]. The results from several studies indicate that MMP-9 mainly cooperates with the $\alpha v \beta 3$ integrin to promote tumor cell motility [68-70]. Specifically, MMP-9 and $\alpha v \beta 3$ often colocalize at the invasive front of cancers, where MMP-9 drives cellular invasion by degrading the tumor matrix, thus clearing the way for $\alpha \mathrm{v} \beta 3$-mediated cancer cell migration (Table 1). In this context, it should be considered that the flexibility of the MMP-9 linker region connecting the catalytic and hemopexin domains optimizes the interaction of migrating cancer cells with MMP-9 substrates [4,68-70]. Moreover, the triggering of $\alpha \mathrm{v} \beta 3$ integrin induces the synthesis of $\beta$-catenin [72], which promotes MMP-9 expression [89].

Of interest, the ability of MMP-9 to favor the spread of tumor cells can also be helped by nonintegrin receptors such as CD44 and CD151, which are coexpressed with MMP-9 by highly invasive cancer cells $[78,79]$. Basically, while CD44 recruits MMP-9 at the protrusions of migrating cells, thereby spatially directing MMP-9 proteolytic activity, CD151 facilitates MMP-9-mediated cancer cell motility by mediating integrin endocytosis at the rear or basal-lateral front of migrating cells (Table 1) [68,78,79]. It is worthy of note that the expression of CD151 and CD44 is upregulated during EMT [79,93].

In conclusion, the mobile/invasive properties of carcinoma cells are strongly enhanced by EMT, which explains the abundance of EMT cells at the invasive front of tumors $[85,86]$. EMT gives tumor 
cells a stem cell-like phenotype, endowing them with plasticity, adaptability and a resilience which allow the subsequent steps of metastasis to occur.

\section{MMP-9 Aids Cancer Cell Trafficking Inside and Outside the Lymphatic or Blood Vessels}

Cancer cells can disseminate in the human body either through local invasion or through blood and/or lymph [93].

Specifically, after degrading the basement membrane and the underlying stroma, migrating cancer cells encounter the abluminal side of lymphatic or blood vessels.

Blood capillaries are formed by an endoluminal face constituted by endothelial cells, and an abluminal side composed of a basement membrane and a noncontinuous lining of vascular smooth muscle cells, the so called pericytes [93]. Therefore, to enter the capillaries, tumor cells must degrade the vascular basement membrane via MMP activity, and then pass through endothelial cells [93,94]. In order to intravasate, cancer cells mainly rely on the MMP-9 they produce [93]. Moreover, MMP-9 released by cancer cells which have undergone a full EMT facilitates the intravasation of cancer cells which have been subjected only to a partial EMT [93]. It is worthy of note that while they degrade the blood vessel basement membrane, cancer cells secrete chemokines and/or cytokines which recruit neutrophils to the endothelium [95-97]. Activated neutrophils, in turn, release TIMP-1-free MMP-9, which effectively aids cancer cells to breach blood vessel walls $[4,11,96,97]$.

At variance with blood capillaries, the lymphatic ones lack either a basement membrane or pericyte coverage, and display open gaps [93]. Therefore, to enter the lymphatic system, tumor cells do not necessarily have to degrade the vascular wall via MMP proteolytic activity [93].

For both blood and lymphatic vessels, tumor cells transmigrate through the endothelium by diapedesis, a process which implies a high degree of cellular deformability which is accomplished through repeated cycles of cell contraction and expansion [98]. The transendothelial migration of EMT cancer cells is facilitated by both VEGF-promoted vascular permeability and the interaction between MMP-9 and neuronal-cadherin [80,81].

Subsequently, single cancer cells or cancer cell clusters shed into the lymphatic system or blood [98].

Generally, the majority of intravasated tumor cells do not come safely through the hematic or lymphatic stream. This is because circulating tumor cells frequently undergo anoikis, a specific type of cell death resulting from the loss of adhesive interactions with the ECM [99]. This notwithstanding, EMT bestows upon tumor cells the ability to resist anoikis as a part of their highly mobile, poorly adhesive phenotype [99]. Anoikis resistance is mediated by EMT-inducing transcription factors; among them, Twist upregulates the expression of the anti-apoptosis Bcl-2 protein, while Snail activates the AKT survival pathways in carcinoma cells [99].

However, cancer cells overcoming anoikis can be assaulted by immune cells [100]. In this context, MMP-9 protects circulating tumor cells from the lethal actions of natural killer cells or cytotoxic T cells $[31,101]$. Specifically, on the lymphocyte surface, MMP-9 degrades the receptor for interleukin-2, a growth and function-activating factor for T cells [31]. Similarly, on the tumor cell membrane, MMP-9 proteolitically cleaves natural killer group 2 member D ligands, thereby lowering tumor cell susceptibility to natural killer cells [101]. Moreover, MMP-9 degrades the C1q component of the complement system [102]: this property of MMP-9 could nullify the humoral immunity directed against cancer cells.

While they are transported by blood or lymph, surviving tumor cells can be entrapped within narrow capillaries, especially when tumor cells aggregate in clusters [98].

The mechanisms through which arrested cancer cells come out of the vessels in anatomic sites close to or distant from the primary tumor are very similar to those employed by neutrophils or monocytes to exit from vessels during inflammation [98]. At the beginning, entrapped tumor cells slide toward the margins of the blood or lymph stream; then, they bind with low affinity to selectins, i.e., adhesion receptors expressed on the endothelial cell membrane [103]. This is because carcinoma cells express selectin ligands such as CD24, CD44 or the carcinoembryonic antigen (Table 1) [75,76,78]. Later, the weakly adherent tumor cells tightly attach to endothelial cells via integrin-mediated 
interactions. For instance, the $\alpha 4 \beta 1$ integrin expressed by carcinoma cells can be bound by the vascular cell adhesion molecule- 1 which is located on the endothelium (Table 1) [77]. In contrast, the $\alpha \mathrm{v} \beta 3$ integrin present on endothelial surface binds to L1, a neural cell adhesion molecule which is aberrantly expressed by some cancer cell types (Table 1) [72].

On the surface of carcinoma cells which have adhered to the endothelium, the CD44 receptor anchors activated MMP-9 and redistributes it at the invading edge of tumor cells, together with the highly proteolytic MT1-MMP [78]. This potentiates and localizes MMP-9-promoted breakdown of the vessel wall required for tumor cell extravasation (Table 1) [104].

\section{MMP-9 Favors Tumor Cell Adaptation to the Microenvironment of the Secondary Site, Hence Effectively Participating in the Establishment of Metastasis}

When disseminated tumor cells arrive at distant organs, they find a microenvironment which differs from that of the organ where the primary tumor developed. Consequently, many of the cancer cells which have reached the secondary site undergo apoptosis, while others enter a state of dormancy in which they stay alive but do not proliferate [2].

Indeed, the successful establishment of the metastasis depends on the formation of a permissive environment within the target secondary organ. Such an environment, termed the premetastatic niche, can be built up by primary tumor cells via the release of molecules supporting the survival and growth of metastatic tumor cells [2]. These molecules diffuse throughout the organism and reach distant organs either free or encapsulated in the exosomes shed from the primary tumor cell surface [2].

Exosomes are small extracellular vesicles of endosomal origin which are released by either cancer cells or normal cells, and contain cellular molecules including nucleic acids, protein or lipids [2].

It is well established that upon their release by a given cell, exosomes interact with another neighbor or distant cell through cellular uptake, fusion with the cell membrane or binding to cell surface receptors [2]. In the context of the metastatic process, exosomes cause cancer and normal cells to communicate with each other in order to build up the premetastatic niche [2].

In addition to exosomes, primary tumor cells release nonencapsulated growth factors (e.g., VEGF or transforming growth factor $\beta 1$ ), cytokines (e.g., tumor necrosis factor $\alpha$ ) or chemokines (e.g., CXCL12) which recruit to the target metastatic site(s)' highly mobile, poorly differentiated cells which are normally involved in tissue repair, such as mesenchymal stem cells and bone marrow-derived myeloid cell precursors [105].

The exosomes, growth factors, cytokines or chemokines released by primary tumor cells, myeloid cell precursors and mesenchymal stem cells modify the phenotype of fibroblasts and macrophages which reside in the metastasis target organ(s). Subsequently, activated fibroblasts subvert the composition, structure and stiffness of the secondary site ECM by secreting collagens, fibronectin, tenascin or periostin. These newly produced ECM molecules activate integrin-mediated signaling pathways in the incoming cancer cells, leading to cancer cell survival and proliferation [106]. For their part, activated macrophages release MMP-9 which further remodels the structure of local ECM to favor the homing of disseminated cancer cells at distant sites [107-109]. Later, exosomes released by normal cells residing in metastasis target organ(s) upregulate MMP-9 expression in the incoming cancer cells [110-113]. Then, exosomes released by tumor cells augment MMP-9 production by partner tumor cells or normal cells which reside in the colonized site(s) [114-121]. This is because exosomes contain microRNAs, chemokines, chemokine receptors, ECM molecules or adhesion receptors which activate transcription factors (e.g., NF-kB) and/or signaling pathways (e.g., MAPK/ERK and PI3K/AKT), leading to MMP-9 expression in target cells [110,111,114,116-120,122-124]. Moreover, exosomes can store active MMPs [124].

The increase in MMP-9 levels at secondary sites helps metastasis establishment and outgrowth by both mediating cancer cell infiltration of the foreign tissue and releasing protumorigenic factors from the ECM $[65,66,92,116]$. 
Soon after they reach the new anatomic site, many of the cancer cells undergo mesenchymal-toepithelial transition (MET); this implies that carcinoma cells reexpress epithelial adherens junctions and lose their EMT, migratory phenotype [93].

MET is promoted by microRNAs (e.g., the miR-200) repressing the function of EMT-inducing transcription factors [93]. In addition, variations in local ECM composition, such as that following proteoglycan depositing by myeloid cell precursors, are particularly effective at promoting MET [125]. Moreover, normal cells residing in secondary sites release integrin-containing exosomes which fuse with the incoming neoplastic cells, thereby rendering them capable of adhering to the foreign tissue ECM, and subsequently surviving and proliferating [126].

In essence, returning to the epithelial phenotype favors metastatic cell proliferation, which is necessary for the development of a clinically relevant metastasis [127-129]. Thus, under the influence of microenvironmental stimuli, cancer cells switch from EMT to MET, with both phenotypes being necessary for the establishment of metastasis.

However, for a metastasis to settle successfully, local antitumor immune responses must be neutralized. Noticeably, MMP-9 counters the anticancer activity of tumor-infiltrating cytotoxic T lymphocytes or natural killer cells [130-132].

The survival and growth of disseminated cancer cells lead to the development of micrometastases in which the number of proliferating tumor cells is close to that of tumor cells undergoing death [133]. The share of proliferating cancer cells increases, and metastases grow in size when new blood vessels supplying oxygen and nutrients to metastatic cancer cells are formed [133]. This is accomplished through a multistep process termed angiogenesis $[73,74]$, whereby endothelial cells lining the endoluminal face of a preexisting local vessel first degrade the vessel basement membrane, and then migrate to the perivascular matrix while proliferating $[73,74]$. This gives rise to endothelial cell solid cords that will ultimately differentiate into hollow tubes, allowing blood flow $[73,74]$. These sequential events are orchestrated by a variety of growth factors, ECM-degrading enzymes and adhesion receptors [73,74]. Among these molecules, MMP-9 plays a prominent role in angiogenesis by cooperating with VEGF and the $\alpha \mathrm{v} \beta 3$ integrin (Table 1) [11,73,74,134-136]. Specifically, the MMP-9 produced by metastatic tumor cells and metastasis-infiltrating neutrophils and/or macrophages breaks down the vessel basement membrane and perivascular matrix, thereby generating ECM fragments $[11,20,26-29,92,134]$. The latter, in turn, trigger $\alpha \mathrm{v} \beta 3$-mediated endothelial cell migration (Table 1) [135]. At the same time, MMP-9 retrieves ECM-bound VEGF in a soluble form which mediates endothelial cell proliferation and endothelial cords differentiation, occurring respectively in the initial and final stages of angiogenesis (Table 1) $[65,73,74,136]$.

Finally, MMP-9 mobilizes endothelial cell precursors from the bone marrow so that they can incorporate into the nascent vasculature of metastasis and then differentiate into mature endothelial cells (Table 1) [82].

It should be remembered that MMP-9 is also important for the angiogenic switch that causes either the growth or the metastatic dissemination of the primary tumor [73,74]. Moreover, in tumor tissue, MMP-9 triggers the formation of new lymphatic vessels, providing additional routes for cancer metastasis [137].

\section{MMP-9 Inhibitors}

Upon their establishment and outgrowth, cancer metastases hamper the function of the colonized organs, which compounds the harmful effect of the primary tumor and significantly worsens the patient's health [1]. Under these circumstances, surgical procedures or combined chemo(radio)therapy are not effective, even though they can successfully treat the majority of nonmetastatic primary tumors [1].

In view of the role that MMPs play in cancer dissemination, during the past thirty years, synthetic MMP inhibitors have been developed and tested for therapeutic efficacy (Table 2). 
Table 2. Mechanism of action, clinical outcomes and toxicities of compounds inhibiting MMP-9 expression and/or activity.

\begin{tabular}{|c|c|c|c|c|}
\hline Drug & Class & Mechanism of Action & Clinical Outcomes & Toxicities \\
\hline MARIMASTAT & $\begin{array}{l}\text { Broad-spectrum } \\
\text { MMPI }\end{array}$ & Chelates MMP catalytic zinc & $\begin{array}{l}\text { Does not improve OS of glioblastoma, NSCLC } \\
\text { and pancreatic or colorectal ca pts [138] }\end{array}$ & Musculoskeletal pain [138] \\
\hline TANOMASTAT & $\begin{array}{l}\text { Narrow-spectrum } \\
\text { MMPI }\end{array}$ & Binds MMP exosite & $\begin{array}{l}\text { Does not improve OS of NSCLC, pancreatic or } \\
\text { ovarian ca pts [139] }\end{array}$ & Nausea, vomiting [139] \\
\hline CURCUMIN & Plant extract & Reduces MMP-9 expression & $\begin{array}{c}\text { Improves the efficacy of chemotherapy in } \\
\text { prostate ca pts [140] }\end{array}$ & None [140] \\
\hline ANDECALIXIMAB & Humanized mAB & Neutralizes MMP-9 & $\begin{array}{l}\text { Improves OS and reduces tumor size in gastric } \\
\text { ca pts [141] }\end{array}$ & Nausea, vomiting, fatigue [141] \\
\hline DOXYCYCLINE & Antibiotic & Reduces MMP-9 expression & Does not improve OS of breast ca pts [142] & Nausea, vomiting, diarrhea [142] \\
\hline LPV-RTV & HIV-PI & $\begin{array}{l}\text { Inhibits the AKT-MMP-9 } \\
\text { pathway }\end{array}$ & effective against CIN [143] & $\begin{array}{l}\text { Increase in glycaemia and/or lipemia } \\
{[[144,145]}\end{array}$ \\
\hline AZT & HIV-RTI & Reduces MMP-9 expression & $\begin{array}{l}\text { Improves the efficacy of chemotherapy in T cell } \\
\text { leukemia pts [146] }\end{array}$ & $\begin{array}{c}\text { Headache, nausea, vomiting, } \\
\text { neutropenia, anemia, hepatotoxicity, } \\
\text { myopathy [147] }\end{array}$ \\
\hline AMD3100 & CXCR4 antagonist & $\begin{array}{l}\text { Inhibits the } \\
\text { CXCL12-AKT-MMP-9 } \\
\text { pathway }\end{array}$ & $\begin{array}{l}\text { Effective against hematological malignancies } \\
\qquad[148,149]\end{array}$ & $\begin{array}{l}\text { Musculoskeletal pain, gastrointestinal } \\
\text { disturbances [150] }\end{array}$ \\
\hline
\end{tabular}


Peptides chelating MMP catalytic zinc via a molecular mimicry of collagens (e.g., BATISTAMAT or MARIMASTAT) have been synthesized and found to counteract the metastatic process in animal models; their use has also been studied in cancer patients [138]. The results from phase II or III clinical trials were not positive because of the poor bioavailability or pharmacokinetics and the dose-limiting musculoskeletal side effects of these drugs (Table 2) [138]. In this regard, it must be stressed that first-generation MMP inhibitors impair the function of all the members of the MMP family at the same time, due to homology between the catalytic domains of these enzymes $[4,138]$. Indeed, the use of multiple drugs simultaneously counteracting all MMPs is not recommended. In fact, these drugs hamper the physiologic processes (e.g., wound healing) that MMPs mediate in a redundant fashion $[3,4]$.

Based on these clinical findings, structural analyses have been performed in order to design compounds specifically inhibiting one or a few MMPs; the results indicated that near MMP active site, an exosite is present which is variable among the MMPs and confers specificity for substrate binding [139]. Hence, additional MMP inhibitors (e.g., TANOMASTAT) have been developed to bind to that exosite, and then chelate the catalytic zinc in a small number of MMPs, MMP-9 included [139]. Unfortunately, these MMP inhibitors have been ineffective in cancer patients (Table 2) [139].

Further efforts have been specifically directed against MMP-9, considering the impact that this enzyme has on cancer metastasis. Results from clinical investigations indicate that natural compounds inhibiting MMP-9 expression or activity, such as QUERCETIN and CURCUMIN, enhance the efficacy of standard antitumor chemotherapy and reduce its side effects (Table 2) [140,151]. Concerning different anti-MMP-9 strategies, humanized anti-MMP-9 monoclonal antibodies (ANDECALIXIMAB) have been explored in gastric cancer patients, and found to be safe (with no indication of musculoskeletal side effects) and moderately effective when combined with classical cytotoxic drugs (Table 2) [141]. In contrast, a cyclic peptide (CILINGITIDE) selectively antagonizing $\alpha \mathrm{v}$ integrins did not inhibit glioblastoma progression [152], despite $\alpha v \beta 3$ actively cooperating with MMP-9 to promote tumor cell dissemination [68-71]. Similarly, the antibiotic DOXYCYCLINE has not been of significant benefit in patients affected by metastatic breast carcinoma (Table 2) [142] —even though the drug is effective against breast carcinoma in animal models [153,154]—or it increases TIMP-1 levels in treated patients [155].

The poor performance of DOXYCYCLINE in anticancer clinical trials is particularly disappointing, as reusing extant medicines is a rapid approach to elaborating antitumor pharmaceuticals [156].

In this regard, however, results from clinical-epidemiological studies have indicated that drugs which have been employed for a long time in the therapy of human immunodeficiency virus (HIV)-1 infection exert direct antitumor activities that are independent of the drug antiviral or immune-reconstituting effects $[48,157]$.

In particular, compounds functionally impairing the HIV aspartyl protease or reverse transcriptase, two enzymes which are pivotal in the replication or infectivity of the virus, have significantly reduced the incidence or progression of HIV-associated tumors [48,157,158]. Further clinical work has indicated that HIV protease or reverse transcriptase inhibitors might also hamper tumor progression in HIV-negative patients (Table 2) [143,159-161].

In this context, preclinical studies have shown that HIV protease inhibitors effectively reduce the growth of highly prevalent human tumors in animal models in the absence of HIV infection [162,163]. In fact, these anti-HIV drugs inhibit events which are key to cancer growth and dissemination, such as ECM breakdown and cell invasion, glycolysis and cell locomotion, fatty acids oxidation and cell proliferation, thereby converting invasive cancer cells into nonmotile cells [164-168].

It is worthy of note that HIV protease inhibitors such as ritonavir, saquinavir, indinavir and lopinavir strongly reduce MMP-9 expression and/or activity in normal or cancer cells and in treated patients [20,169-174]. This is because HIV protease inhibitors repress the MAPK/ERK and/or PI3K/AKT signaling pathways, thereby functionally impairing transcription factors targeting the $m m p-9$ gene, including NF-kB, Specificity protein-1 or the Fra-1 element of the Activator Protein-1 transcriptional 
complex [164,169,175-196]. It should be noted that the AKT activation process starts when PI3K promotes the production of phosphatidylinositol-3,4,5-trisphosphate (PIP3); this is followed by AKT recruitment to the cell membrane and AKT phosphorylation on Thr308 and Ser473 by the phosphoinosotide-dependent kinase-1 and the mammalian target of rapamycin, respectively [191]. In this context, the HIV-protease inhibitor nelfinavir impairs AKT phosphorylation by hampering AKT recruitment to the cell membrane. The finding that nelfinavir does not reduce PIP3 production suggests that the drug may lower PIP3 sensing by AKT $[190,191]$. Moreover, nelfinavir can impair the mammalian target of rapamycin, which is both an activator and a downstream target of AKT [182]. For its part, the HIV-protease inhibitor ritonavir dephosphorylates AKT by reducing the levels of heat shock protein $90[183,186]$. Finally, with regard to MAPK activation, it should be emphasized that the HIV-protease inhibitors indinavir and nelfinavir dephosphorylate mitogen-activated protein kinase $1 / 2$, which prevents the downstream activation of MAPKs [178,180]. Specifically concerning nelfinavir, it dephosphorylates mitogen-activated protein kinase $1 / 2$ by augmenting protein-phosphatase- 2 activity [180].

Additional studies suggest that HIV protease inhibitors could impair MMP-9 activity also because of their ability to upregulate TIMPs levels [171,197], diminish the production of nitric oxide and reduce the expression of MT1-MMP [192,198-201]. The fact that they reduce the expression of MMPs while increasing that of TIMPs makes HIV-protease inhibitors similar to natural compounds that perform these actions thanks to the same ability to hamper the AKT and MAPK signaling pathways [202,203]. Also, synthetic antagonists of $\alpha 1$-antitrypsin, an endogenous protease inhibitor which is overexpressed in tumor tissues, downregulate MMPs and, at the same time, upregulate TIMPs via PI3K/AKT inhibition [204]. It is worthy of note that the HIV-protease inhibitor ritonavir reduces $\alpha 1$-antitrypsin protein levels in treated patients [205]. Future work will evaluate whether $\alpha 1$-antitrypsin is involved in the antitumor activities of HIV-protease inhibitors.

Consistent with their antagonist effect on MMPs, HIV protease inhibitors block ECM invasion by cancer cells or endothelial cells, thereby halting both tumor dissemination and angiogenesis [20,48,157,162,163,169,192,206].

The anti-angiogenic activity of HIV-protease inhibitors is particularly interesting, since combining standard chemo(radio)therapy with anti-angiogenic strategies has been shown to improve the prognosis of cancer patients, consistent with the fact that angiogenesis sustains tumor cell growth and spread throughout the organism [74,207].

In this context, it has to be highlighted that due to their repressive activity on HIF-1 or NF-kB, HIV-protease inhibitors downregulate the expression of VEGF, the most potent inducer of tumor angiogenesis [175-177,193].

Indeed, VEGF antagonists including multikinase inhibitors and antibodies targeting VEGF or its type-2 receptor represent a group of anti-angiogenetic drugs that is widely used at present [73]. However, the extended application of these VEGF inhibitors causes adverse effects encompassing high blood pressure, impaired wound healing or hemostasis, proteinuria and gastrointestinal ulceration [73]. Moreover, long-term-treated patients become insensitive to these drugs, as the inhibition of the VEGF pathway triggers the production of other angiogenic factors [208]. In this respect, HIV-protease inhibitors promise to be more effective than classical VEGF antagonists, as they halt angiogenesis by blocking MMP proinvasive activity, regardless of the involved angiogenic factor $[162,192,206]$.

Although it largely contributes to the angiogenic switch required for metastasis outgrowth, MMP-9 can generate anti-angiogenic compounds (e.g., tumstatin and endostatin) resulting from the proteolytic cleavage of ECM molecules [12,13]. In this regard, however, one should consider that inhibiting MMP-9 is unlikely to significantly reduce the levels of anti-angiogenic ECM fragments, since they can also be generated by other MMPs [12,13].

Clinical trials recruiting HIV-infected or uninfected individuals have shown that when HIV-protease inhibitors are administered together with standard chemo(radio)therapy, they promote the regression of advanced carcinomas [209,210]. In contrast, HIV-protease inhibitor monotherapy 
is active against early- but not late-stage tumors [48,143,159,211-214]. However, it should be noted that despite their multiple antitumor effects, first generation HIV-protease inhibitors (e.g., ritonavir, nelfinavir and lopinavir) augment glycemia and/or lipemia in treated patients (Table 2) [144,145]. Concerning second generation HIV-protease inhibitors (e.g., darunavir and atazanavir), they display only minor toxicities [215], but their antitumor activities are not yet well-defined.

The HIV-reverse transcriptase inhibitors zidovudine and lamivudine can downregulate MMP-9 expression in normal or tumor cells, weaken MAPK/ERK or PI3K/AKT phosphorylation, reduce nitric oxide production and impair angiogenesis [174,216-218]. In contrast, other HIV-reverse transcriptase inhibitors (e.g., tenofovir and efavirenz) are able to exert either pro- or anti- tumor activities $[217,219]$.

Results from medical tests indicate that, when combined with standard antitumor cytotoxic drugs, zidovudine is effective against T cell leukemia (Table 2) [146], while efavirenz slows prostate carcinoma progression and lamivudine reduces the incidence of hepatocellular carcinoma [160,161].

Nausea, vomiting, diarrhea, headache and/or rash often occur in HIV-positive individuals taking HIV-reverse transcriptase inhibitors (Table 2) $[147,220,221]$. Moreover, the long-term use of these drugs has been reported to cause neutropenia, anemia, myopathy, and liver or kidney malfunction (Table 2) $[147,220,221]$.

Therefore, current work is exploring the antitumor activity of AMD3100, an antagonist of the CXC chemokine receptor 4 (CXCR4) which has been in use for some time for HIV-infected individuals, as it efficiently counteracts virus entry into target cells [222]. Reassuringly, AMD3100 clinical adoption entails only mild side effects, including transient musculoskeletal pain and/or gastrointestinal disturbances (Table 2) [150].

The rational for the use of AMD3100 in oncology is that CXCR4 binding by natural ligands, such as the CXCL12 chemokine, triggers PI3K/AKT, thereby promoting MMP-9 expression [223] and cancer cell invasion/dissemination [224-228]. Consistently, AMD3100 has reduced MMP-9 production and hampered cancer metastasis in preclinical models [229].

At present, AMD3100 is successfully being used in the treatment of hematological malignancies (Table 2) [148,149]. Indeed, results from observational studies encourage the use of AMD3100 against a broader spectrum of neoplasms, solid tumors included [230-232].

\section{Conclusions and Future Directions}

The expression and/or activity of MMP-9 are increased in different types of human tumors, playing a major role in their progression [43-53]. In particular, MMP-9 is pivotal in all steps of the metastatic process, in that it strongly contributes to the ability that cancer cells have to: (1) disrupt the cell-to-cell or cell-to-ECM interactions that maintain the primary tumor mass; (2) penetrate local ECM and vessels; (3) exit the vessel and migrate into the extravascular space; and (4) survive and proliferate in foreign tissue $[1,3,10,11]$.

Accordingly, MMP-9 expression level is believed to reliably monitor cancer clinical progression [44-53].

Moreover, MMP-9 is considered a valid antitumor target. In this respect, a variety of approaches have been pursued, although much work remains to be done. In particular, broad-spectrum MMP inhibitors have failed in clinical trials due to their lack of selectivity and dose-limiting, severe side effects [138]. For their part, compounds directed at reducing MMP-9 activity have not reached the required efficacy [139-142,151].

The good news is that inhibitors of HIV protease or reverse transcriptase and CXCR4 antagonists, which have been used for many years to counter HIV infection, effectively inhibit MMP-9 expression and tumor cell dissemination [20,157-161,169-174,216,227].

In this regard, results from preclinical studies indicate that HIV-protease inhibitors compromise a wide variety of metabolic or signaling pathways which are pivotal in cancer cell survival, proliferation and locomotion [48,157]. In contrast, the anticancer activities of HIV-reverse transcriptase inhibitors appear to be more limited, as these drugs impair some protumor pathways while favoring others [174,216-219]. 
Probably one of the most relevant anticancer activities of HIV-protease inhibitors is their ability to hamper the AKT signaling pathway [183-191]. In this respect, HIV-protease inhibitors may resemble novel AKT inhibitors such as IDELALISIB and COPANLISIB, which were recently approved for clinical use in various types of cancer [233]. However, one should consider that, at variance with novel AKT inhibitors, HIV-protease inhibitors have been utilized for a long time in the treatment of HIV-infected individuals, and their tissue distribution and pharmacokinetics are well known [215].

As for HIV-protease inhibitors, antagonists of the CXCL12/CXCR4 axis also switch off the AKT-MMP pathway; however, HIV-protease inhibitors reduce the levels of both total and phosphorylated AKT $[175,176,183-191]$, while CXCR4 antagonists cannot prevent CXCL12 binding to other chemokine receptors which are able to turn on AKT phosphorylation and MMP expression [83].

Results from clinical trials indicate that HIV-protease inhibitors are more efficacious in the early (premetastatic) stages of tumor progression [48,143,157,159]; this observation suggests that the HIV-protease inhibitors could be explored for metastases prevention in early-stage cancers overexpressing MMP-9. Although their repurposing for tumor therapy appears feasible, the long-term administration of HIV-protease inhibitors causes harmful side effects, such as hyperlipemia and hyperglycemia $[144,145,215]$. Based on structural analyses, preclinical studies and clinical tests, further research should conceive and evaluate HIV-protease inhibitor analogs which are endowed with activities that are as restricted as possible to the anticancer one.

It is well established that the antitumor efficacy of HIV-protease inhibitors augments when they are administered in combination with standard chemotherapy or radiotherapy $[210,234,235]$. Given the role that inflammation and the immune response play in promoting and contrasting tumor growth, respectively, in the near future, clinical trials should evaluate whether the anticancer activities of HIV-protease inhibitors could be potentiated also by anti-inflammatory drugs and/or compounds enforcing antitumor immune surveillance. Likely candidates could be cyclooxygenase- 2 inhibitors or antibodies directed against negative regulators of $\mathrm{T}$ cell responses, as both of these classes of drugs have been shown to be of significant benefit in cancer patients [236,237].

Funding: This study was supported by the Italian Ministry of Health (grant no. OR/0906).

Acknowledgments: The author thanks B. Ensoli, E. Toschi, C. Sgadari, P. Monini, C. Palladino, P. Leone, A. Iovane and I. Bacigalupo (National Institute of Health, Rome, Italy) for the work done together to evaluate the impact of HIV-protease inhibitors on MMPs, angiogenesis, tumor growth and cancer cell invasion.

Conflicts of Interest: The author declares no conflict of interest.

\section{Abbreviations}

$\begin{array}{ll}\text { AKT } & \text { protein kinase B } \\ \text { CXCL } & \text { CXC chemokine ligand } \\ \text { CXCR } & \text { CXC chemokine receptor } \\ \text { ECM } & \text { extracellular matrix } \\ \text { EMT } & \text { epithelial-to-mesenchymal transition } \\ \text { ERK } & \text { extracellular signal-regulated kinase } \\ \text { HIF } & \text { hypoxia inducible factor } \\ \text { HIV } & \text { human immunodeficiency virus } \\ \text { MAPK } & \text { mitogen activated protein kinase } \\ \text { MET } & \text { mesenchymal-to-epithelial transition } \\ \text { MMP } & \text { matrix metalloproteinase } \\ \text { MT-MMP } & \text { membrane type-matrix metalloproteinase } \\ \text { NF-kB } & \text { nuclear factor-kappa B } \\ \text { PI3K } & \text { phosphoinositide 3 kinase } \\ \text { PIP3 } & \text { phosphatidylinositol-3,4,5-trisphosphate } \\ \text { TIMP } & \text { tissue inhibitor of matrix metalloproteinase } \\ \text { VEGF } & \text { vascular endothelial growth factor }\end{array}$




\section{References}

1. Welch, D.R.; Hurst, D.R. Defining the Hallmarks of Metastasis. Cancer Res. 2019, 79, 3011-3027. [CrossRef] [PubMed]

2. Høye, A.; Erler, J.T. Structural ECM components in the premetastatic and metastatic niche. Am. J. Physiol. Physiol. 2016, 310, C955-C967. [CrossRef] [PubMed]

3. Cui, N.; Hu, M.; Khalil, R.A. Biochemical and Biological Attributes of Matrix Metalloproteinases. Prog. Mol. Biol. Transl. Sci. 2017, 147, 1-73. [CrossRef] [PubMed]

4. Vandooren, J.; Van den Steen, P.E.; Opdenakker, G. Biochemistry and molecular biology of gelatinase B or matrix metalloproteinase-9 (MMP-9): The next decade. Crit. Rev. Biochem. Mol. Biol. 2013, 48, 222-272. [CrossRef] [PubMed]

5. Itoh, Y. Membrane-Type matrix metalloproteinases: Their functions and regulations. Matrix Biol. 2015, 44, 207-223. [CrossRef] [PubMed]

6. Arpino, V.; Brock, M.; Gill, S.E. The role of TIMPs in regulation of extracellular matrix proteolysis. Matrix Biol. 2015, 44, 247-254. [CrossRef] [PubMed]

7. Fingleton, B. Matrix metalloproteinases as regulators of inflammatory processes. Biochim. Biophys. Acta Mol. Cell Res. 2017, 1864, 2036-2042. [CrossRef]

8. Stanciu, A.E.; Zamfir-Chiru-Anton, A.; Stanciu, M.; Popescu, C.; Gheorghe, D. Imbalance between Matrix Metalloproteinases and Tissue Inhibitors of Metalloproteinases Promotes Invasion and Metastasis of Head and Neck Squamous Cell Carcinoma. Clin. Lab. 2017, 63, 1613-1620. [CrossRef]

9. Yao, Q.; Kou, L.; Tu, Y.; Zhu, L. MMP-Responsive 'Smart' Drug Delivery and Tumor Targeting. Trends Pharmacol. Sci. 2018, 39, 766-781. [CrossRef]

10. Huang, H. Matrix Metalloproteinase-9 (MMP-9) as a Cancer Biomarker and MMP-9 Biosensors: Recent Advances. Sensors 2018, 18, 3249. [CrossRef]

11. Hurt, B.; Schulick, R.; Edil, B.; El Kasmi, K.C.; Barnett, C. Cancer-Promoting mechanisms of tumor-Associated neutrophils. Am. J. Surg. 2017, 214, 938-944. [CrossRef] [PubMed]

12. Walia, A.; Yang, J.; Huang, Y.-H.; Rosenblatt, M.I.; Chang, J.-H.; Azar, D.T. Endostatin's emerging roles in angiogenesis, lymphangiogenesis, disease, and clinical applications. Biochim. Biophys. Acta 2015, 1850, 2422-2438. [CrossRef] [PubMed]

13. Hamano, Y.; Zeisberg, M.; Sugimoto, H.; Lively, J.C.; Maeshima, Y.; Yang, C.; Hynes, R.O.; Werb, Z.; Sudhakar, A.; Kalluri, R. Physiological levels of tumstatin, a fragment of collagen IV alpha3 chain, are generated by MMP-9 proteolysis and suppress angiogenesis via alphaV beta3 integrin. Cancer Cell 2003, 3, 589-601. [CrossRef]

14. Fouad, H.; Salem, H.; Ellakwa, D.E.-S.; Abdel-Hamid, M. MMP-2 and MMP-9 as prognostic markers for the early detection of urinary bladder cancer. J. Biochem. Mol. Toxicol. 2018, 33, e22275. [CrossRef] [PubMed]

15. Guo, H.; Dai, Y.; Wang, A.; Wang, C.; Sun, L.; Wang, Z. Association between expression of MMP-7 and MMP-9 and pelvic lymph node and para-Aortic lymph node metastasis in early cervical cancer. J. Obstet. Gynaecol. Res. 2018, 44, 1274-1283. [CrossRef] [PubMed]

16. Shimura, T.; Dagher, A.; Sachdev, M.; Ebi, M.; Yamada, T.; Joh, T.; Moses, M. Urinary ADAM12 and MMP-9/NGAL Complex Detect the Presence of Gastric Cancer. Cancer Prev. Res. 2015, 8, 240-248. [CrossRef]

17. Newby, A. Metalloproteinase production from macrophages-Perfect storm leading to atherosclerotic plaque rupture and myocardial infarction. Exp. Physiol. 2016, 101, 1327-1337. [CrossRef]

18. Du, M.; Wang, Y.; Liu, Z.; Wang, L.; Cao, Z.; Zhang, C.; Hao, Y.; He, H. Effects of IL-1 $\beta$ on MMP-9 Expression in Cementoblast-Derived Cell Line and MMP-Mediated Degradation of Type I Collagen. Inflammation 2019, 42, 413-425. [CrossRef]

19. Ding, X.-W.; Sun, X.; Shen, X.-F.; Lu, Y.; Wang, J.-Q.; Sun, Z.-R.; Miao, C.-H.; Chen, J. Propofol attenuates TNF- $\alpha$-induced MMP-9 expression in human cerebral microvascular endothelial cells by inhibiting Ca2+/CAMK II/ERK/NF-kB signaling pathway. Acta Pharmacol. Sin. 2019, 40, 1303-1313. [CrossRef]

20. Barillari, G.; Iovane, A.; Bacigalupo, I.; Palladino, C.; Bellino, S.; Leone, P.; Monini, P.; Ensoli, B. Ritonavir or saquinavir impairs the invasion of cervical intraepithelial neoplasia cells via a reduction of MMP expression and activity. AIDS 2012, 26, 909-919. [CrossRef] 
21. Chen, Y.-J.; Lee, Y.-C.; Huang, C.-H.; Chang, L.-S. Gallic acid-capped gold nanoparticles inhibit EGF-induced MMP-9 expression through suppression of p300 stabilization and NFKB/c-Jun activation in breast cancer MDA-MB-231 cells. Toxicol. Appl. Pharmacol. 2016, 310, 98-107. [CrossRef] [PubMed]

22. Muscella, A.; Vetrugno, C.; Cossa, L.G.; Marsigliante, S. TGF- $\beta 1$ activates RSC96 Schwann cells migration and invasion through MMP-2 and MMP-9 activities. J. Neurochem. 2019, 153, 525-538. [CrossRef]

23. Wang, C.-Y.; Tsai, H.-L.; Syu, J.-S.; Chen, T.-Y.; Su, M.-T. Primary Cilium-Regulated EG-VEGF Signaling Facilitates Trophoblast Invasion. J. Cell. Physiol. 2016, 232, 1467-1477. [CrossRef] [PubMed]

24. Shen, B.; Zheng, M.-Q.; Lu, J.-W.; Jiang, Q.; Wang, T.-H.; Huang, X.-E. CXCL12-CXCR4 Promotes Proliferation and Invasion of Pancreatic Cancer Cells. Asian Pac. J. Cancer Prev. 2013, 14, 5403-5408. [CrossRef] [PubMed]

25. Saravani, R.; Yari, D.; Hasanian-Langroudi, F. Correlation between the COL4A3, MMP-9, and TIMP-1 polymorphisms and risk of keratoconus. Jpn. J. Ophthalmol. 2017, 61, 218-222. [CrossRef] [PubMed]

26. Veidal, S.S.; Larsen, D.; Chen, X.; Sun, S.; Zheng, Q.; Bay-Jensen, A.-C.; Leeming, D.; Nawrocki, A.; Larsen, M.R.; Schett, G.; et al. MMP mediated type V collagen degradation (C5M) is elevated in ankylosing spondylitis. Clin. Biochem. 2012, 45, 541-546. [CrossRef] [PubMed]

27. Van Doren, S.R. Matrix metalloproteinase interactions with collagen and elastin. Matrix Biol. 2015, 44, $224-231$. [CrossRef]

28. Li, W.; Liu, Z.; Zhao, C.; Zhai, L. Binding of MMP-9-Degraded fibronectin to ?6 integrin promotes invasion via the FAK-Src-Related Erk1/2 and PI3K/Akt/Smad-1/5/8 pathways in breast cancer. Oncol. Rep. 2015, 34, 1345-1352. [CrossRef]

29. Darweish, M.M.; Abbas, A.; Ebrahim, M.A.; Al-Gayyar, M.H. Chemopreventive and hepatoprotective effects of Epigallocatechin-Gallate against hepatocellular carcinoma: Role of heparan sulfate proteoglycans pathway. J. Pharm. Pharmacol. 2014, 66, 1032-1045. [CrossRef]

30. Van den Steen, P.E.; Husson, S.J.; Proost, P.; Van Damme, J.; Opdenakker, G. Carboxyterminal cleavage of the chemokines MIG and IP-10 by gelatinase B and neutrophil collagenase. Biochem. Biophys. Res. Commun. 2003, 310, 889-896. [CrossRef]

31. Sheu, B.C.; Hsu, S.M.; Ho, H.N.; Lien, H.C.; Huang, S.C.; Lin, R.H. A novel role of metalloproteinase in cancer-Mediated immunosuppression. Cancer Res. 2001, 61, 237-242. [PubMed]

32. Philipp, K.; Riedel, F.; Sauerbier, M.; Hormann, K.; Germann, G. Targeting TGF-Beta in human keratinocytes and its potential role in wound healing. Int. J. Mol. Med. 2004, 14, 589-593. [CrossRef] [PubMed]

33. Van Der Kooij, M.A.; Fantin, M.; Rejmak-Kozicka, E.; Grosse, J.; Zanoletti, O.; Fournier, C.; Ganguly, K.; Kalita, K.; Kaczmarek, L.; Sandi, C. Role for MMP-9 in stress-Induced downregulation of nectin-3 in hippocampal CA1 and associated behavioural alterations. Nat. Commun. 2014, 5, 4995. [CrossRef] [PubMed]

34. Liu, R.; Tan, Q.; Luo, Q. Decreased expression level and DNA-Binding activity of specificity protein 1 via cyclooxygenase-2 inhibition antagonizes radiation resistance, cell migration and invasion in radiation-resistant lung cancer cells. Oncol. Lett. 2018, 16, 3029-3037. [CrossRef]

35. Yang, J.; Wei, D.; Liu, J. Repressions of MMP-9 expression and NF- $\mathrm{kB}$ localization are involved in inhibition of lung carcinoma 95-D cell invasion by (-)-epigallocatechin-3-gallate. Biomed. Pharmacother. 2005, 59, 98-103. [CrossRef]

36. Nazir, S.U.; Kumar, R.; Singh, A.; Khan, A.; Tanwar, P.; Tripathi, R.; Mehrotra, R.; Hussain, S. Breast cancer invasion and progression by MMP-9 through Ets-1 transcription factor. Gene 2019, 711, 143952. [CrossRef]

37. Wang, P.; Zhang, L.D.; Sun, M.C.; Gu, W.D.; Geng, H.Z. Over-Expression of mir-124 inhibits MMP-9 expression and decreases invasion of renal cell carcinoma cells. Eur. Rev. Med. Pharmacol. Sci. 2018, 22, 6308-6314. [CrossRef]

38. Wang, W.; Yang, C.; Wang, X.Y.; Zhou, L.Y.; Lao, G.J.; Wang, C.; Liu, D.; Hu, M.D.; Zeng, T.T.; Yan, L.; et al. MicroRNA-129 and -335 Promote Diabetic Wound Healing by Inhibiting Sp1-Mediated MMP-9 Expression. Diabetes 2018, 67, 1627-1638. [CrossRef]

39. Li, Z.; Takino, T.; Endo, Y.; Sato, H. Activation of MMP-9 by membrane type-1 MMP/MMP-2 axis stimulates tumor metastasis. Cancer Sci. 2017, 108, 347-353. [CrossRef]

40. Gilardoni, M.B.; Remedi, M.M.; Oviedo, M.; DellaVedova, T.; Sarría, J.P.; Racca, L.; Dominguez, M.; Pellizas, C.G.; Donadio, A.C. Differential expression of Low density lipoprotein Receptor-Related Protein 1 (LRP-1) and matrix metalloproteinase-9 (MMP-9) in prostate gland: From normal to malignant lesions. Pathol. Res. Pract. 2017, 213, 66-71. [CrossRef] 
41. Chan, C.Y.; Chan, Y.C.; Cheuk, B.L.; Cheng, S.W. Clearance of matrix metalloproteinase-9 is dependent on low-Density lipoprotein receptor-Related protein-1 expression downregulated by microRNA-205 in human abdominal aortic aneurysm. J. Vasc. Surg. 2017, 65, 509-520. [CrossRef] [PubMed]

42. Rodriguez-Calvo, R.; Ferrán, B.; Alonso, J.; Martí-Pàmies, Í.; Aguiló, S.; Calvayrac, O.; Rodríguez, C.; Martínez-González, J. NR4A receptors up-Regulate the antiproteinase alpha-2 macroglobulin (A2M) and modUlate MMP-2 and MMP-9 in vascular smooth muscle cells. Thromb. Haemost. 2015, 113, $1323-1334$. [CrossRef] [PubMed]

43. Li, X.; Huang, Q.; Wang, S.; Huang, Z.; Yu, F.; Lin, J. HER4 promotes the growth and metastasis of osteosarcoma via the PI3K/AKT pathway. Acta Biochim. Biophys. Sin. 2020, 52, 345-362. [CrossRef] [PubMed]

44. Pelekanou, V.; Villarroel-Espindola, F.; Schalper, K.A.; Pusztai, L.; Rimm, D.L. CD68, CD163, and matrix metalloproteinase 9 (MMP-9) co-localization in breast tumor microenvironment predicts survival differently in ER-positive and negative cancers. Breast Cancer Res. 2018, 20, 154. [CrossRef] [PubMed]

45. Yang, B.; Tang, F.; Zhang, B.; Zhao, Y.; Feng, J.; Rao, Z. Matrix metalloproteinase-9 overexpression is closely related to poor prognosis in patients with colon cancer. World J. Surg. Oncol. 2014, 12, 24. [CrossRef]

46. Dong, Y.-Z.; Meng, X.-M.; Li, G.-S. Long non-coding RNA SNHG15 indicates poor prognosis of non-Small cell lung cancer and promotes cell proliferation and invasion. Eur. Rev. Med Pharmacol. Sci. 2018, 22, 2671-2679. [CrossRef]

47. Li, Y.-M.; Liu, Z.-Y.; Li, Z.-C.; Wang, J.-C.; Yu, J.-M.; Yang, H.-J.; Chen, Z.-N.; Tang, J. Alterations of the Immunologic Co-Stimulator B7 and TNFR Families Correlate with Hepatocellular Carcinoma Prognosis and Metastasis by Inactivating STAT3. Int. J. Mol. Sci. 2019, 20, 156. [CrossRef]

48. Barillari, G.; Monini, P.; Sgadari, C.; Ensoli, B. The Impact of Human Papilloma Viruses, Matrix Metallo-Proteinases and HIV Protease Inhibitors on the Onset and Progression of Uterine Cervix Epithelial Tumors: A Review of Preclinical and Clinical Studies. Int. J. Mol. Sci. 2018, 19, 1418. [CrossRef]

49. Bedkowska, G.; Piskór, B.; Gacuta, E.; Zajkowska, M.; Osada, J.; Szmitkowski, M.; Dąbrowska, M.; Ławicki, S. Diagnostic Power of Selected Cytokines, MMPs and TIMPs in Ovarian Cancer Patients-ROC Analysis. Anticancer Res. 2019, 39, 2575-2582. [CrossRef]

50. Pryczynicz, A.; Guzińska-Ustymowicz, K.; Dymicka-Piekarska, V.; Czyzewska, J.; Kemona, A. Expression of matrix metalloproteinase 9 in pancreatic ductal carcinoma is associated with tumor metastasis formation. Folia Histochem. Cytobiol. 2007, 45, 37-40.

51. Yao, Z.; Yuan, T.; Wang, H.; Yao, S.; Zhao, Y.; Liu, Y.; Jin, S.; Chu, J.; Xu, Y.; Zhou, W.; et al. MMP-2 together with MMP-9 overexpression correlated with lymph node metastasis and poor prognosis in early gastric carcinoma. Tumor Biol. 2017, 39. [CrossRef] [PubMed]

52. Ghallab, N.A.; Shaker, O.G. Serum and salivary levels of chemerin and MMP-9 in oral squamous cell carcinoma and oral premalignant lesions. Clin. Oral Investig. 2016, 21, 937-947. [CrossRef] [PubMed]

53. Chen, Y.-S.; Hung, T.-W.; Su, S.C.; Lin, C.-L.; Yang, S.-F.; Lee, C.-C.; Yeh, C.-F.; Hsieh, Y.-H.; Tsai, J.-P. MTA2 as a Potential Biomarker and Its Involvement in Metastatic Progression of Human Renal Cancer by miR-133b Targeting MMP-9. Cancers 2019, 11, 1851. [CrossRef] [PubMed]

54. Li, S.; Zhang, S.; Chen, J. c-Myc induced upregulation of long non-coding RNA SNHG16 enhances progression and carcinogenesis in oral squamous cell carcinoma. Cancer Gene Ther. 2019, 26, 400-410. [CrossRef] [PubMed]

55. Liu, H.; Ren, G.; Wang, T.; Chen, Y.; Gong, C.; Bai, Y.; Wang, B.; Qi, H.; Shen, J.; Zhu, L.; et al. Aberrantly expressed Fra-1 by IL-6/STAT3 transactivation promotes colorectal cancer aggressiveness through epithelial-mesenchymal transition. Carcinogenesis 2015, 36, 459-468. [CrossRef] [PubMed]

56. Powell, E.; Piwnica-Worms, D.; Piwnica-Worms, H. Contribution of p53 to metastasis. Cancer Discov. 2014, 4, 405-414. [CrossRef] [PubMed]

57. Lee, S.Y.; Ju, M.K.; Jeon, H.M.; Lee, Y.J.; Kim, C.H.; Park, H.G.; Han, S.I.; Kang, H.S. Oncogenic Metabolism Acts as a Prerequisite Step for Induction of Cancer Metastasis and Cancer Stem Cell Phenotype. Oxid. Med. Cell. Longev. 2018, 2018, 1-28. [CrossRef]

58. Yang, H.-Y.; Shen, J.-X.; Wang, Y.; Liu, Y.; Shen, D.-Y.; Quan, S. Tankyrase Promotes Aerobic Glycolysis and Proliferation of Ovarian Cancer through Activation of Wnt/ß-Catenin Signaling. BioMed Res. Int. 2019, 2019. [CrossRef]

59. Vaupel, P.; Multhoff, G. Fatal Alliance of Hypoxia-/HIF-1 $\alpha$-Driven Microenvironmental Traits Promoting Cancer Progression. Adv. Exp. Med. Biol. 2020, 1232, 169-176. [CrossRef] 
60. Furman, D.; Campisi, J.; Verdin, E.; Carrera-Bastos, P.; Targ, S.; Franceschi, C.; Ferrucci, L.; Gilroy, D.W.; Fasano, A.; Miller, G.W.; et al. Chronic inflammation in the etiology of disease across the life span. Nat. Med. 2019, 25, 1822-1832. [CrossRef]

61. Olea-Flores, M.O.; Zuñiga-Eulogio, M.D.; Mendoza-Catalan, M.A.; Rodríguez-Ruiz,H.A.; Castañeda-Saucedo, E.; Ortuno-Pineda, C.; Padilla-Benavides, T.; Navarro-Tito, N. Extracellular-Signal Regulated Kinase: A Central Molecule Driving Epithelial-Mesenchymal Transition in Cancer. Int. J. Mol. Sci. 2019, 20, 2885. [CrossRef]

62. Jang, H.-Y.; Hong, O.-Y.; Youn, H.J.; Kim, M.-G.; Kim, C.-H.; Jung, S.H. 15d-PGJ2 inhibits NF-кB and AP-1-mediated MMP-9 expression and invasion of breast cancer cell by means of a heme oxygenase-1-dependent mechanism. BMB Rep. 2020, 53, 212-217. [CrossRef] [PubMed]

63. Bove, P.F.; Wesley, U.V.; Greul, A.-K.; Hristova, M.; Dostmann, W.R.; Van Der Vliet, A. Nitric Oxide Promotes Airway Epithelial Wound Repair through Enhanced Activation of MMP-9. Am. J. Respir. Cell Mol. Biol. 2006, 36, 138-146. [CrossRef] [PubMed]

64. Liu, S.; Jiang, J.; Huang, L.; Jiang, Y.; Yu, N.; Liu, X.; Lv, Y.; Li, H.; Zou, L.; Peng, C.; et al. iNOS is associated with tumorigenicity as an independent prognosticator in human intrahepatic cholangiocarcinoma. Cancer Manag. Res. 2019, 11, 8005-8022. [CrossRef]

65. Sidibé, A.; Ropraz, P.; Jemelin, S.; Emre, Y.; Poittevin, M.; Pocard, M.; Bradfield, P.F.; Imhof, B.A. Angiogenic factor-driven inflammation promotes extravasation of human proangiogenic monocytes to tumours. Nat. Commun. 2018, 9, 355. [CrossRef] [PubMed]

66. Dallas, S.L.; Rosser, J.L.; Mundy, G.R.; Bonewald, L.F. Proteolysis of latent transforming growth factor-beta (TGF-beta)-binding protein-1 by osteoclasts. A cellular mechanism for release of TGF-beta from bone matrix. J. Biol. Chem. 2002, 277, 21352-21360. [CrossRef] [PubMed]

67. Jackson, H.W.; Defamie, V.; Waterhouse, P.; Khokha, R. TIMPs: Versatile extracellular regulators in cancer. Nat. Rev. Cancer 2016, 17, 38-53. [CrossRef]

68. Hamidi, H.; Ivaska, J. Every step of the way: Integrins in cancer progression and metastasis. Nat. Rev. Cancer 2018, 18, 533-548. [CrossRef]

69. Liapis, H.; Flath, A.; Kitazawa, S. Integrin alpha V beta 3 expression by bone-Residing breast cancer metastases. Diagn. Mol. Pathol. 1996, 5, 127-135. [CrossRef]

70. Gasparini, G.; Brooks, P.C.; Biganzoli, E.; Vermeulen, P.B.; Bonoldi, E.; Dirix, L.Y.; Ranieri, G.; Miceli, R.; Cheresh, D.A. Vascular integrin alpha(v)beta3: A new prognostic indicator in breast cancer. Clin. Cancer Res. 1998, 4, 2625-2634.

71. Weingarten, C.; Jenudi, Y.; Tshuva, R.Y.; Moskovich, D.; Alfandari, A.; Hercbergs, A.; Davis, P.J.; Ellis, M.; Ashur-Fabian, O. The Interplay between epithelial-Mesenchymal transition (EMT) and the thyroid hormones- $\alpha v \beta 3$ axis in ovarian cancer. Horm. Cancer 2017, 9, 22-32. [CrossRef] [PubMed]

72. Montgomery, A.M.; Becker, J.C.; Siu, C.H.; Lemmon, V.P.; Cheresh, D.A.; Pancook, J.D.; Zhao, X.; Reisfeld, R.A. Human neural cell adhesion molecule L1 and rat homologue NILE are ligands for integrin alpha v beta 3. J. Cell Biol. 1996, 132, 475-485. [CrossRef] [PubMed]

73. Ridiandries, A.; Tan, J.; Bursill, C.A. The Role of CC-Chemokines in the Regulation of Angiogenesis. Int. J. Mol. Sci. 2016, 17, 1856. [CrossRef]

74. Petrillo, S.; Tolosano, E.; Munaron, L.; Genova, T. Targeting Metabolism to Counteract Tumor Angiogenesis: A Review of Patent Literature. Recent Pat. Anti-Cancer Drug Discov. 2018, 13, 422-427. [CrossRef] [PubMed]

75. Myung, J.H.; Gajjar, K.A.; Pearson, R.M.; Launiere, C.A.; Eddington, D.T.; Hong, S. Direct Measurements on CD24-Mediated Rolling of Human Breast Cancer MCF-7 Cells on E-Selectin. Anal. Chem. 2011, 83, 1078-1083. [CrossRef]

76. Thomas, S.N.; Zhu, F.; Schnaar, R.L.; Alves, C.S.; Konstantopoulos, K. Carcinoembryonic Antigen and CD44 Variant Isoforms Cooperate to Mediate Colon Carcinoma Cell Adhesion to E- and L-selectin in Shear Flow. J. Biol. Chem. 2008, 283, 15647-15655. [CrossRef]

77. Sökeland, G.; Schumacher, U. The functional role of integrins during intra- and extravasation within the metastatic cascade. Mol. Cancer 2019, 18, 12. [CrossRef]

78. Yu, Q.; Stamenkovic, I. Localization of matrix metalloproteinase 9 to the cell surface provides a mechanism for CD44-mediated tumor invasion. Genome Res. 1999, 13, 35-48. [CrossRef]

79. Yu, Y.; Liang, C.; Wang, S.; Zhu, J.; Miao, C.; Hua, Y.; Bao, M.; Cao, Q.; Qin, C.; Shao, P.; et al. CD151 promotes cell metastasis via activating TGF- $\beta 1 /$ Smad signaling in renal cell carcinoma. Oncotarget 2018, 9, 13313-13323. [CrossRef] 
80. Hsu, C.C.; Huang, S.F.; Wang, J.S.; Chu, W.K.; Nien, J.E.; Chen, W.S.; Chow, SE. Interplay of N-cadherin and matrix metalloproteinase 9 enhances human nasopharyngeal carcinoma cell invasion. BMC Cancer 2016, 16, 800. [CrossRef]

81. Criscuoli, M.L.; Nguyen, M.; Eliceiri, B.P. Tumor metastasis but not tumor growth is dependent on Src-mediated vascular permeability. Blood 2005, 105, 1508-1514. [CrossRef] [PubMed]

82. Ratajska, A.; Jankowska-Steifer, E.; Czarnowska, E.; Olkowski, R.; Gula, G.; Niderla-Bielińska, J.; Flaht-Zabost, A.; Jasińska, A. Vasculogenesis and its cellular therapeutic applications. Cells Tissues Organs 2017, 203, 141-152. [CrossRef] [PubMed]

83. Tamma, R.; Ribatti, D. Bone Niches, Hematopoietic Stem Cells, and Vessel Formation. Int. J. Mol. Sci. 2017, 18, 151. [CrossRef] [PubMed]

84. Chiasson-MacKenzie, C.; McClatchey, A.I. Cell-Cell Contact and Receptor Tyrosine Kinase Signaling. Cold Spring Harb. Perspect. Biol. 2017, 10, a029215. [CrossRef]

85. Yeung, K.T.; Yang, J. Epithelial-Mesenchymal transition in tumor metastasis. Mol. Oncol. 2016, 11, $28-39$. [CrossRef] [PubMed]

86. Zhang, Y.; Weinberg, R.A. Epithelial-to-Mesenchymal transition in cancer: Complexity and opportunities. Front. Med. 2018, 12, 361-373. [CrossRef]

87. Chen, L.; Yang, F.; Li, T.; Xiao, P.; Han, Z.-J.; Shu, L.-F.; Yuan, Z.-Z.; Liu, W.-J.; Long, Y.-Q. Extracellular Histone Promotes Prostate Cancer Migration and Epithelial-Mesenchymal Transition through NF-kB-Mediated Inflammatory Responses. Chemotherapy 2019, 64, 177-186. [CrossRef]

88. Pezzuto, A.; Carico, E.; Aldo, P.; Elisabetta, C. Role of HIF-1 in Cancer Progression: Novel Insights. A Review. Curr. Mol. Med. 2019, 18, 343-351. [CrossRef]

89. Kreiseder, B.; Orel, L.; Bujnow, C.; Buschek, S.; Pflueger, M.; Schuett, W.; Hundsberger, H.; Martin, R.; Wiesner, C. $\alpha$-Catulin downregulates E-cadherin and promotes melanoma progression and invasion. Int. J. Cancer 2012, 132, 521-530. [CrossRef]

90. Vinnakota, K.; Zhang, Y.; Selvanesan, B.C.; Topi, G.; Salim, T.; Sand-Dejmek, J.; Jönsson, G.; Sjölander, A. M2-like macrophages induce colon cancer cell invasion via matrix metalloproteinases. J. Cell. Physiol. 2017, 232, 3468-3480. [CrossRef]

91. Vaisar, T.; Kassim, S.Y.; Gomez, I.G.; Green, P.S.; Hargarten, S.; Gough, P.J.; Parks, W.C.; Wilson, C.L.; Raines, E.W.; Heinecke, J.W. MMP-9 sheds the beta2 integrin subunit (CD18) from macrophages. Mol. Cell. Proteom. 2008, 8, 1044-1060. [CrossRef] [PubMed]

92. Wells, J.M.; Gaggar, A.; Blalock, J.E. MMP generated matrikines. Matrix Biol. 2015, 44, 122-129. [CrossRef]

93. Banyard, J.; Bielenberg, D.R. The role of EMT and MET in cancer dissemination. Connect. Tissue Res. 2015, 56, 403-413. [CrossRef] [PubMed]

94. Hsieh, S.-L.; Hsieh, S.; Lai, P.-Y.; Wang, J.-J.; Li, C.-C.; Wu, C.-C. Carnosine Suppresses Human Colorectal Cell Migration and Intravasation by Regulating EMT and MMP Expression. Am. J. Chin. Med. 2019, 47, 477-494. [CrossRef] [PubMed]

95. Su, S.; Liu, Q.; Chen, J.; Chen, J.; Chen, F.; He, C.; Huang, D.; Wu, W.; Lin, L.; Huang, W.; et al. A Positive Feedback Loop between Mesenchymal-like Cancer Cells and Macrophages Is Essential to Breast Cancer Metastasis. Cancer Cell 2014, 25, 605-620. [CrossRef]

96. Galdiero, M.R.; Varricchi, G.; Loffredo, S.; Bellevicine, C.; Lansione, T.; Ferrara, A.L.; Iannone, R.; Di Somma, S.; Borriello, F.; Clery, E.; et al. Potential involvement of neutrophils in human thyroid cancer. PLoS ONE 2018, 13, e0199740. [CrossRef]

97. Wu, L.; Awaji, M.; Saxena, S.; Varney, M.L.; Sharma, B.; Singh, R.K. IL-17-CXC Chemokine Receptor 2 Axis Facilitates Breast Cancer Progression by Up-Regulating Neutrophil Recruitment. Am. J. Pathol. 2019, 190, 222-233. [CrossRef]

98. Reymond, N.; d'Água, B.B.; Ridley, A.J. Crossing the endothelial barrier during metastasis. Nat. Rev. Cancer 2013, 13, 858-870. [CrossRef]

99. Cao, Z.; Livas, T.; Kyprianou, N. Anoikis and EMT: Lethal "Liaisons" during Cancer Progression. Crit. Rev. Oncog. 2016, 21, 155-168. [CrossRef]

100. Mohme, M.; Riethdorf, S.; Pantel, K. Circulating and disseminated tumour cells-Mechanisms of immune surveillance and escape. Nat. Rev. Clin. Oncol. 2016, 14, 155-167. [CrossRef] 
101. Shiraishi, K.; Mimura, K.; Kua, L.-F.; Koh, V.; Siang, L.K.; Nakajima, S.; Fujii, H.; Shabbir, A.; Yong, W.-P.; So, J.B.; et al. Inhibition of MMP activity can restore NKG2D ligand expression in gastric cancer, leading to improved NK cell susceptibility. J. Gastroenterol. 2016, 51, 1101-1111. [CrossRef] [PubMed]

102. Ruiz, S.; Henschen-Edman, A.H.; Nagase, H.; Tenner, A.J. Digestion of C1q collagen-Like domain with MMPs-1, -2,- 3, and -9 further defines the sequence involved in the stimulation of neutrophil superoxide production. J. Leukoc. Biol. 1999, 66, 416-422. [CrossRef]

103. Dabagh, M.; Gounley, J.; Randles, A. Localization of Rolling and Firm-Adhesive Interactions Between Circulating Tumor Cells and the Microvasculature Wall. Cell. Mol. Bioeng. 2020, 13, 141-154. [CrossRef] [PubMed]

104. Voura, E.B.; English, J.L.; Yu, H.-Y.; Van Ho, A.T.; Subarsky, P.; Hill, R.P.; Hojilla, C.V.; Khokha, R. Proteolysis during Tumor Cell Extravasation In Vitro: Metalloproteinase Involvement across Tumor Cell Types. PLoS ONE 2013, 8, e78413. [CrossRef] [PubMed]

105. Alvarez, M.V.; Gutierrez, L.M.; Correa, A.; Lazarowski, A.; Bolontrade, M. Metastatic Niches and the Modulatory Contribution of Mesenchymal Stem Cells and Its Exosomes. Int. J. Mol. Sci. 2019, 20, 1946. [CrossRef] [PubMed]

106. Cooper, J.; Giancotti, F.G. Integrin Signaling in Cancer: Mechanotransduction, Stemness, Epithelial Plasticity, and Therapeutic Resistance. Cancer Cell 2019, 35, 347-367. [CrossRef]

107. Zhang, J.; Han, X.; Shi, H.; Gao, Y.; Qiao, X.; Li, H.; Wei, M.; Zeng, X. Lung resided monocytic myeloid-derived suppressor cells contribute to premetastatic niche formation by enhancing MMP-9 expression. Mol. Cell. Probes 2020, 50, 101498. [CrossRef]

108. Vered, M.; Shnaiderman-Shapiro, A.; Schiby, G.; Zlotogorski-Hurvitz, A.; Salo, T.; Yahalom, R. Markers of the pre-Metastatic niche "knock on the door" of metastasis-Free cervical lymph nodes in patients with oral cancer. Acta Histochem. 2019, 121, 151447. [CrossRef]

109. Wu, S.; Zheng, Q.; Xing, X.; Dong, Y.; Wang, Y.; You, Y.; Chen, R.; Hu, C.; Chen, J.; Gao, D.; et al. Matrix stiffness-Upregulated LOXL2 promotes fibronectin production, MMP9 and CXCL12 expression and BMDCs recruitment to assist pre-Metastatic niche formation. J. Exp. Clin. Cancer Res. 2018, 37, 99. [CrossRef]

110. Li, M.; Lu, Y.; Xu, Y.; Wang, J.; Zhang, C.; Du, Y.; Wang, L.; Li, L.; Wang, B.; Shen, J.; et al. Horizontal transfer of exosomal CXCR4 promotes murine hepatocarcinoma cell migration, invasion and lymphangiogenesis. Gene 2018, 676, 101-109. [CrossRef]

111. Li, Y.Y.; Tao, Y.W.; Gao, S.; Li, P.; Zheng, J.M.; Zhang, S.E.; Liang, J.; Zhang, Y. Cancer-Associated fibroblasts contribute to oral cancer cells proliferation and metastasis via exosome-Mediated paracrine miR-34a-5p. EBioMedicine 2018, 36, 209-220. [CrossRef] [PubMed]

112. Cai, Z.; Yang, F.; Yu, L.; Yu, Z.; Jiang, L.; Wang, Q.; Yang, Y.; Wang, L.; Cao, X.; Wang, J. Activated T Cell Exosomes Promote Tumor Invasion via Fas Signaling Pathway. J. Immunol. 2012, 188, 5954-5961. [CrossRef]

113. Janowska-Wieczorek, A.; Wysoczynski, M.; Kijowski, J.; Marquez-Curtis, L.; Machalinski, B.; Ratajczak, J.; Ratajczak, M.Z. Microvesicles derived from activated platelets induce metastasis and angiogenesis in lung cancer. Int. J. Cancer 2004, 113, 752-760. [CrossRef] [PubMed]

114. Sun, S.; Chen, H.; Xu, C.; Zhang, Y.; Zhang, Q.; Chen, L.; Ding, Q.; Deng, Z. Exosomal miR-106b serves as a novel marker for lung cancer and promotes cancer metastasis via targeting PTEN. Life Sci. 2020, 244, 117297. [CrossRef] [PubMed]

115. Ma, Z.; Cui, X.; Lu, L.; Chen, G.; Yang, Y.; Hu, Y.; Lu, Y.; Cao, Z.; Wang, Y.; Wang, X. Exosomes from glioma cells induce a tumor-Like phenotype in mesenchymal stem cells by activating glycolysis. Stem Cell Res. Ther. 2019, 10, 60. [CrossRef] [PubMed]

116. Linton, S.S.; Abraham, T.; Liao, J.; Clawson, G.A.; Butler, P.J.; Fox, T.; Kester, M.; Matters, G.L. Tumor-promoting effects of pancreatic cancer cell exosomes on THP-1-Derived macrophages. PLoS ONE 2018, 13, e0206759. [CrossRef]

117. Zhou, X.; Yan, T.; Huang, C.; Xu, Z.; Wang, L.; Jiang, E.; Wang, H.; Chen, Y.; Liu, K.; Shao, Z.; et al. Melanoma cell-secreted exosomal miR-155-5p induce proangiogenic switch of cancer-associated fibroblasts via SOCS1/JAK2/STAT3 signaling pathway. J. Exp. Clin. Cancer Res. 2018, 37, 242. [CrossRef]

118. Mutschelknaus, L.; Azimzadeh, O.; Heider, T.; Winkler, K.; Vetter, M.; Kell, R.; Tapio, S.; Merl-Pham, J.; Huber, S.M.; Edalat, L.; et al. Radiation alters the cargo of exosomes released from squamous head and neck cancer cells to promote migration of recipient cells. Sci. Rep. 2017, 7, 12423. [CrossRef] 
119. Purushothaman, A.; Bandari, S.K.; Liu, J.; Mobley, J.A.; Brown, E.E.; Sanderson, R.D. Fibronectin on the Surface of Myeloma Cell-Derived Exosomes Mediates Exosome-Cell Interactions. J. Biol. Chem. 2015, 291, 1652-1663. [CrossRef]

120. He, M.; Qin, H.; Poon, T.C.; Sze, S.-C.; Ding, X.; Na Co, N.; Ngai, S.-M.; Chan, T.-F.; Wong, N. Hepatocellular carcinoma-Derived exosomes promote motility of immortalized hepatocyte through transfer of oncogenic proteins and RNAs. Carcinogenesis 2015, 36, 1008-1018. [CrossRef]

121. Chen, G.; Zhang, Y.; Wu, X. 786-0 Renal cancer cell line-Derived exosomes promote 786-0 cell migration and invasion in vitro. Oncol. Lett. 2014, 7, 1576-1580. [CrossRef] [PubMed]

122. Corrado, C.; Saieva, L.; Raimondo, S.; Santoro, A.; De Leo, G.; Alessandro, R. Chronic myelogenous leukaemia exosomes modulate bone marrow microenvironment through activation of epidermal growth factor receptor. J. Cell. Mol. Med. 2016, 20, 1829-1839. [CrossRef] [PubMed]

123. Yang, C.; Luo, L.; Bai, X.; Shen, K.; Liu, K.; Wang, J.; Hu, D. Highly-Expressed micoRNA-21 in adipose derived stem cell exosomes can enhance the migration and proliferation of the HaCaT cells by increasing the MMP-9 expression through the PI3K/AKT pathway. Arch. Biochem. Biophys. 2020,681, 108259. [CrossRef] [PubMed]

124. Runz, S.; Keller, S.; Rupp, C.; Stoeck, A.; Issa, Y.; Koensgen, D.; Mustea, A.; Sehouli, J.; Kristiansen, G.; Altevogt, P. Malignant ascites-Derived exosomes of ovarian carcinoma patients contain CD24 and EpCAM. Gynecol. Oncol. 2007, 107, 563-571. [CrossRef] [PubMed]

125. Gao, D.; Joshi, N.; Choi, H.; Ryu, S.; Hahn, M.; Catena, R.; Sadik, H.; Argani, P.; Wagner, P.; Vahdat, L.; et al. Myeloid Progenitor Cells in the Premetastatic Lung Promote Metastases by Inducing Mesenchymal to Epithelial Transition. Cancer Res. 2012, 72, 1384-1394. [CrossRef]

126. Hoshino, A.; Costa-Silva, B.; Shen, T.-L.; Rodrigues, G.; Hashimoto, A.; Mark, M.T.; Molina, H.; Kohsaka, S.; Di Giannatale, A.; Ceder, S.; et al. Tumour exosome integrins determine organotropic metastasis. Nature 2015, 527, 329-335. [CrossRef]

127. Thiery, J.P. Epithelial-mesenchymal transitions in tumour progression. Nat. Rev. Cancer 2002, 2, $442-454$. [CrossRef]

128. Scheel, C.; Weinberg, R.A. Cancer stem cells and epithelial-Mesenchymal transition: Concepts and molecular links. Semin. Cancer Biol. 2012, 22, 396-403. [CrossRef]

129. Tsai, J.H.; Donaher, J.L.; Murphy, D.A.; Chau, S.; Yang, J. Spatiotemporal regulation of epithelial-Mesenchymal transition is essential for squamous cell carcinoma metastasis. Cancer Cell 2012, 22, 725-736. [CrossRef]

130. Lee, B.K.; Kim, M.J.; Jang, H.S.; Lee, H.R.; Ahn, K.M.; Lee, J.H.; Choung, P.H.; Kim, M.J. A high concentration of MMP-2/gelatinase A and MMP-9/gelatinase B reduce NK cell-Mediated cytotoxicity against an oral squamous cell carcinoma cell line. In Vivo 2008, 22, 593-597.

131. Peng, Y.-P.; Zhang, J.-J.; Liang, W.-B.; Tu, M.; Lu, Z.; Wei, J.; Jiang, K.; Gao, W.; Wu, J.; Xu, Z.; et al. Elevation of MMP-9 and IDO induced by pancreatic cancer cells mediates natural killer cell dysfunction. BMC Cancer 2014, 14, 738. [CrossRef] [PubMed]

132. Juric, V.; O'Sullivan, C.; Stefanutti, E.; Kovalenko, M.; Greenstein, A.; Barry-Hamilton, V.; Mikaelian, I.; Degenhardt, J.; Yue, P.; Smith, V.; et al. MMP-9 inhibition promotes anti-Tumor immunity through disruption of biochemical and physical barriers to T-Cell trafficking to tumors. PLoS ONE 2018, 13, e0207255. [CrossRef] [PubMed]

133. Barkan, D.; Green, J.E.; Chambers, A. Extracellular matrix: A gatekeeper in the transition from dormancy to metastatic growth. Eur. J. Cancer 2010, 46, 1181-1188. [CrossRef] [PubMed]

134. Liu, Y.; Zhang, H.; Yan, L.; Du, W.; Zhang, M.; Chen, H.; Zhang, L.; Li, G.; Li, J.; Dong, Y.; et al. MMP-2 and MMP-9 contribute to the angiogenic effect produced by hypoxia/15-HETE in pulmonary endothelial cells. J. Mol. Cell. Cardiol. 2018, 121, 36-50. [CrossRef]

135. Naik, M.U.; Naik, U.M. Junctional adhesion molecule-A-Induced endothelial cell migration on vitronectin is integrin alpha v beta 3 specific. J. Cell Sci. 2006, 119, 490-499. [CrossRef]

136. Li, G.-J.; Yang, Y.; Yang, G.-K.; Wan, J.; Cui, D.-L.; Ma, Z.-H.; Du, L.-J.; Zhang, G.-M. Slit2 suppresses endothelial cell proliferation and migration by inhibiting the VEGF-Notch signaling pathway. Mol. Med. Rep. 2017, 15, 1981-1988. [CrossRef]

137. Yoo, Y.A.; Kang, M.H.; Lee, H.J.; Kim, B.-H.; Park, J.K.; Kim, H.K.; Kim, J.S.; Oh, S.C. Sonic Hedgehog Pathway Promotes Metastasis and Lymphangiogenesis via Activation of Akt, EMT, and MMP-9 Pathway in Gastric Cancer. Cancer Res. 2011, 71, 7061-7070. [CrossRef] 
138. Peterson, J.T. The importance of estimating the therapeutic index in the development of matrix metalloproteinase inhibitors. Cardiovasc. Res. 2006, 69, 677-687. [CrossRef]

139. Hirte, H.; Vergote, I.; Jeffrey, J.; Grimshaw, R.; Coppieters, S.; Schwartz, B.; Tu, D.; Sadura, A.; Brundage, M.; Seymour, L. A phase III randomized trial of BAY 12-9566 (tanomastat) as maintenance therapy in patients with advanced ovarian cancer responsive to primary surgery and paclitaxel/platinum containing chemotherapy: A National Cancer Institute of Canada Clinical Trials Group Study. Gynecol. Oncol. 2006, 102, 300-308. [CrossRef]

140. Tan, B.L.; Esa, N.M. Curcumin Combination Chemotherapy: The Implication and Efficacy in Cancer. MolEcules 2019, 24, 2527. [CrossRef]

141. Shah, M.A.; Starodub, A.N.; Sharma, S.; Berlin, J.; Patel, M.R.; Wainberg, Z.A.; Chaves, J.; Gordon, M.S.; Windsor, K.; Brachmann, C.B.; et al. Andecaliximab/GS-5745 Alone and Combined with mFOLFOX6 in Advanced Gastric and Gastroesophageal Junction Adenocarcinoma: Results from a Phase I Study. Clin. Cancer Res. 2018, 24, 3829-3837. [CrossRef]

142. Addison, C.; Simos, D.; Wang, Z.; Pond, G.; Smith, S.; Robertson, S.; Mazzarello, S.; Singh, G.; VanderMeer, L.; Fernandes, R.; et al. A phase 2 trial exploring the clinical and correlative effects of combining doxycycline with bone-targeted therapy in patients with metastatic breast cancer. J. Bone Oncol. 2016, 5, 173-179. [CrossRef]

143. Hampson, L.; Maranga, I.O.; Masinde, M.S.; Oliver, A.W.; Batman, G.; He, X.; Desai, M.; Okemwa, P.M.; Stringfellow, H.; Martin-Hirsch, P.; et al. A Single-Arm, Proof-of-Concept Trial of Lopimune (Lopinavir/Ritonavir) as a Treatment for HPV-Related Pre-Invasive Cervical Disease. PLoS ONE 2016, 11, e0147917. [CrossRef] [PubMed]

144. Anastos, K.; Lu, D.; Shi, Q.; Tien, P.C.; Kaplan, R.C.; Hessol, N.A.; Cole, S.; Vigen, C.; Cohen, M.; Young, M.; et al. Association of Serum Lipid Levels With HIV Serostatus, Specific Antiretroviral Agents, and Treatment Regimens. J. Acquir. Immune Defic. Syndr. 2007, 45, 34-42. [CrossRef]

145. Mulligan, K.; Grunfeld, C.; Tai, V.W.; Algren, H.; Pang, M.; Chernoff, D.N.; Lo, J.C.; Schambelan, M. Hyperlipidemia and Insulin Resistance Are Induced by Protease Inhibitors Independent of Changes in Body Composition in Patients With HIV Infection. J. Acquir. Immune Defic. Syndr. 2000, 23, 35-43. [CrossRef] [PubMed]

146. Kchour, G.; Tarhini, M.; Kooshyar, M.M.; El Hajj, H.; Wattel, E.; Mahmoudi, M.; Hatoum, H.; Rahimi, H.; Maleki, M.; Rafatpanah, H.; et al. Phase 2 study of the efficacy and safety of the combination of arsenic trioxide, interferon alpha, and zidovudine in newly diagnosed chronic adult T-Cell leukemia/lymphoma (ATL). Blood 2009, 113, 6528-6532. [CrossRef] [PubMed]

147. Leroi, C.; Balestre, E.; Messou, E.; Minga, A.; Sawadogo, A.; Drabo, J.; Maïga, M.; Zannou, M.; Seydi, M.; Dabis, F.; et al. Incidence of Severe Neutropenia in HIV-Infected People Starting Antiretroviral Therapy in West Africa. PLoS ONE 2017, 12, e0170753. [CrossRef] [PubMed]

148. Bhamidipati, P.K.; Fiala, M.A.; Grossman, B.J.; DiPersio, J.F.; Stockerl-Goldstein, K.; Gao, F.; Uy, G.L.; Westervelt, P.; Schroeder, M.A.; Cashen, A.F.; et al. Results of a Prospective Randomized, Open-Label, Noninferiority Study of Tbo-Filgrastim (Granix) versus Filgrastim (Neupogen) in Combination with Plerixafor for Autologous Stem Cell Mobilization in Patients with Multiple Myeloma and Non-Hodgkin Lymphoma. Biol. Blood Marrow Transpl. 2017, 23, 2065-2069. [CrossRef]

149. Martínez-Cuadrón, D.; Boluda, B.; Martinez, P.; Bergua, J.; Rodríguez-Veiga, R.; Esteve, J.; Vives, S.; Serrano, J.; Vidriales, B.; Salamero, O.; et al. A phase I-II study of plerixafor in combination with fludarabine, idarubicin, cytarabine, and G-CSF (PLERIFLAG regimen) for the treatment of patients with the first early-relapsed or refractory acute myeloid leukemia. Ann. Hematol. 2018, 97, 763-772. [CrossRef]

150. Cashen, A.F.; Rettig, M.; Gao, F.; Smith, A.; Abboud, C.; Stockerl-Goldstein, K.; Vij, R.; Uy, G.L.; Westervelt, P.; DiPersio, J. Phase I/II Study of Intravenous Plerixafor Added to a Mobilization Regimen of Granulocyte Colony-Stimulating Factor in Lymphoma Patients Undergoing Autologous Stem Cell Collection. Biol. Blood Marrow Transpl. 2017, 23, 1282-1289. [CrossRef]

151. Neuwirthová, J.; Gal, B.; Smilek, P.; Urbánková, P. Potential of the Flavonoid Quercetin to Prevent and Treat Cancer-Current Status of Research. Klin. Onkol. 2018, 31, 184-190. [CrossRef] [PubMed]

152. Eisele, G.; Wick, A.; Eisele, A.-C.; Clement, P.M.; Tonn, J.; Tabatabai, G.; Ochsenbein, A.; Schlegel, U.; Neyns, B.; Krex, D.; et al. Cilengitide treatment of newly diagnosed glioblastoma patients does not alter patterns of progression. J. Neurooncol. 2014, 117, 141-145. [CrossRef] [PubMed] 
153. Mira, E.; LaCalle, R.A.; Buesa, J.M.; De Buitrago, G.G.; Jiménez-Baranda, S.; Gómez-Moutón, C.; Martínez-A, C.; Manes, S. Secreted MMP9 promotes angiogenesis more efficiently than constitutive active MMP9 bound to the tumor cell surface. J. Cell Sci. 2004, 117, 1847-1857. [CrossRef]

154. Tang, X.; Wang, X.; Zhao, Y.; Curtis, J.M.; Brindley, D.N. Doxycycline attenuates breast cancer related inflammation by decreasing plasma lysophosphatidate concentrations and inhibiting NF- $\mathrm{BB}$ activation. Mol. Cancer 2017, 16, 36. [CrossRef] [PubMed]

155. Górska, R.; Nedzi-Gora, M. The effects of the initial treatment phase and of adjunctive low-dose doxycycline therapy on clinical parameters and MMP-8, MMP-9, and TIMP-1 levels in the saliva and peripheral blood of patients with chronic periodontitis. Arch. Immunol. Ther. Exp. 2006, 54, 419-426. [CrossRef]

156. Cha, Y.; Erez, T.; Reynolds, I.J.; Kumar, D.; Ross, J.; Koytiger, G.; Kusko, R.; Zeskind, B.; Risso, S.; Kagan, E.; et al. Drug repurposing from the perspective of pharmaceutical companies. Br. J. Pharmacol. 2017, 175, 168-180. [CrossRef]

157. Monini, P.; Sgadari, C.; Toschi, E.; Barillari, G.; Ensoli, B. Antitumour effects of antiretroviral therapy. Nat. Rev. Cancer 2004, 4, 861-875. [CrossRef] [PubMed]

158. Shepherd, F.A.; Beaulieu, R.; Gelmon, K.; Thuot, C.A.; Sawka, C.; Read, S.; Singer, J. Prospective randomized trial of two dose levels of interferon alfa with zidovudine for the treatment of Kaposi's sarcoma associated with human immunodeficiency virus infection: A Canadian HIV Clinical Trials Network study. J. Clin. Oncol. 1998, 16, 1736-1742. [CrossRef]

159. Monini, P.; Sgadari, C.; Grosso, M.G.; Bellino, S.; Di Biagio, A.; Toschi, E.; Bacigalupo, I.; Sabbatucci, M.; Cencioni, G.; Salvi, E.; et al. Clinical course of classic Kaposi's sarcoma in HIV-Negative patients treated with the HIV protease inhibitor indinavir. AIDS 2009, 23, 534-538. [CrossRef]

160. Houédé, N.; Pulido, M.; Mourey, L.; Joly, F.; Ferrero, J.-M.; Bellera, C.A.; Priou, F.; Lalet, C.; Laroche-Clary, A.; Raffin, M.C.; et al. A Phase II Trial Evaluating the Efficacy and Safety of Efavirenz in Metastatic Castration-Resistant Prostate Cancer. Oncologist 2014, 19, 1227-1228. [CrossRef]

161. Yoo, J.; Hann, H.-W.; Coben, R.; Conn, M.; Dimarino, A.J. Update Treatment for HBV Infection and Persistent Risk for Hepatocellular Carcinoma: Prospect for an HBV Cure. Diseases 2018, 6, 27. [CrossRef]

162. Toschi, E.; Sgadari, C.; Malavasi, L.; Bacigalupo, I.; Chiozzini, C.; Carlei, D.; Compagnoni, D.; Bellino, S.; Bugarini, R.; Falchi, M.; et al. Human immunodeficiency virus protease inhibitors reduce the growth of human tumors via a proteasome-Independent block of angiogenesis and matrix metalloproteinases. Int. J. Cancer 2010, 128, 82-93. [CrossRef] [PubMed]

163. Esposito, V.; Verdina, A.; Manente, L.; Spugnini, E.P.; Viglietti, R.; Parrella, R.; Pagliano, P.; Parrella, G.; Galati, R.; De Luca, A.; et al. Amprenavir inhibits the migration in human hepatocarcinoma cell and the growth of xenografts. J. Cell. Physiol. 2012, 228, 640-645. [CrossRef]

164. Song, S.; Ji, Y.; Zhang, G.; Zhang, X.; Li, B.; Li, D.; Jiang, W. Protective Effect of Atazanavir Sulphate Against Pulmonary FibrosisIn VivoandIn Vitro. Basic Clin. Pharmacol. Toxicol. 2017, 122, 199-207. [CrossRef] [PubMed]

165. Whelan, K.T.; Lin, C.-L.; Cella, M.; McMichael, A.J.; Austyn, J.M.; Rowland-Jones, S.L. The HIV protease inhibitor Indinavir reduces immature dendritic cell transendothelial migration. Eur. J. Immunol. 2003, 33, 2520-2530. [CrossRef]

166. Sanchez, C.G.; Molinski, S.; Gongora, R.; Sosulski, M.; Fuselier, T.; MacKinnon, S.S.; Mondal, D.; Lasky, J.A. The antiretroviral agent nelfinavir mesylate: a potential therapy for systemic sclerosis. Arthritis Rheumatol. 2017, 70, 115-126. [CrossRef] [PubMed]

167. Hresko, R.C.; Hruz, P.W. HIV Protease Inhibitors Act as Competitive Inhibitors of the Cytoplasmic Glucose Binding Site of GLUTs with Differing Affinities for GLUT1 and GLUT4. PLoS ONE 2011, 6, e25237. [CrossRef]

168. Richmond, S.R.; Carper, M.J.; Lei, X.; Zhang, S.; Yarasheski, K.; Ramanadham, S. HIV-Protease inhibitors suppress skeletal muscle fatty acid oxidation by reducing CD36 and CPT1 fatty acid transporters. Biochim. Biophys. Acta 2010, 1801, 559-566. [CrossRef] [PubMed]

169. Bacigalupo, I.; Palladino, C.; Leone, P.; Toschi, E.; Sgadari, C.; Ensoli, B.; Barillari, G. Inhibition of MMP-9 expression by ritonavir or saquinavir is associated with inactivation of the AKT/Fra-1 pathway in cervical intraepithelial neoplasia cells. Oncol. Lett. 2017, 13, 2903-2908. [CrossRef] [PubMed]

170. De Barros, S.; Zakaroff-Girard, A.; Lafontan, M.; Galitzky, J.; Bourlier, V. Inhibition of human preadipocyte proteasomal activity by HIV protease inhibitors or specific inhibitor lactacystin leads to a defect in adipoGenesis, which involves MMP-9. J. Pharmacol. Exp. Ther. 2006, 320, 291-299. [CrossRef] 
171. Latronico, T.; Liuzzi, G.M.; Riccio, P.; Lichtner, M.; Mengoni, F.; D’Agostino, C.; Vullo, V.; Mastroianni, C.M. Antiretroviral therapy inhibits matrix metalloproteinase- 9 from blood mononuclear cells of HIV-infected patients. AIDS 2007, 21, 677-684. [CrossRef] [PubMed]

172. Kennedy, A.; Hennessy, M.; Bergin, C.; Mulcahy, F.; Hopkins, S.; Spiers, J.P. Ribavirin and interferon alter MMP-9 abundance in vitro and in HIV-HCV-Coinfected patients. Antivir. Ther. 2011, 16, 1237-1247. [CrossRef] [PubMed]

173. Latronico, T.; Pati, I.; Ciavarella, R.; Fasano, A.; Mengoni, F.; Lichtner, M.; Vullo, V.; Mastroianni, C.M.; Liuzzi, G.M. In vitro effect of antiretroviral drugs on cultured primary astrocytes: Analysis of neurotoxicity and matrix metalloproteinase inhibition. J. Neurochem. 2018, 144, 271-284. [CrossRef] [PubMed]

174. Liuzzi, G.M.; Mastroianni, C.M.; Latronico, T.; Mengoni, F.; Fasano, A.; Lichtner, M.; Vullo, V.; Riccio, P. Anti-HIV drugs decrease the expression of matrix metalloproteinases in astrocytes and microglia. Brain 2004, 127, 398-407. [CrossRef]

175. Pore, N.; Gupta, A.K.; Cerniglia, G.J.; Maity, A. HIV Protease Inhibitors Decrease VEGF/HIF-1 $\alpha$ Expression and Angiogenesis in Glioblastoma Cells. Neoplasia 2006, 8, 889-895. [CrossRef]

176. Gupta, A.K.; Cerniglia, G.J.; Jiang, Z.; Bernhard, E.J.; Evans, S.M.; Koch, C.J.; Hahn, S.M.; Maity, A. Nelfinavir down-Regulates hypoxia-Inducible factor 1alpha and VEGF expression and increases tumor oxygenation: implications for radiotherapy. Cancer Res. 2006, 66, 9252-9259. [CrossRef]

177. Ikezoe, T.; Saito, T.; Bandobashi, K.; Yang, Y.; Koeffler, H.P.; Taguchi, H. HIV-1 protease inhibitor induces growth arrest and apoptosis of human multiple myeloma cells via inactivation of signal transducer and activator of transcription 3 and extracellular signal-Regulated kinase 1/2. Mol. Cancer Ther. 2004, 3, 473-479.

178. Hong-Brown, L.Q.; Brown, C.R.; Lang, C.H. Indinavir impairs protein synthesis and phosphorylations of MAPKs in mouse C2C12 myocytes. Am. J. Physiol. Physiol. 2004, 287, C1482-C1492. [CrossRef]

179. Ravaud, C.; Paré, M.; Yao, X.; Azoulay, S.; Mazure, N.M.; Dani, C.; Ladoux, A. Resveratrol and HIV-protease inhibitors control UCP1 expression through opposite effects on p38 MAPK phosphorylation in human adipocytes. J. Cell. Physiol. 2019, 235, 1184-1196. [CrossRef]

180. Wallet, M.A.; Reist, C.M.; Williams, J.C.; Appelberg, S.; Guiulfo, G.L.; Gardner, B.; Sleasman, J.W.; Goodenow, M.M. The HIV-1 protease inhibitor nelfinavir activates PP2 and inhibits MAPK signaling in macrophages: A pathway to reduce inflammation. J. Leukoc. Biol. 2012, 92, 795-805. [CrossRef]

181. Jensen, K.; Bikas, A.; Patel, A.; Kushchayeva, Y.; Costello, J.; McDaniel, D.; Burman, K.; Vasko, V. Nelfinavir inhibits proliferation and induces DNA damage in thyroid cancer cells. Endocr. Relat. Cancer 2017, 24, 147-156. [CrossRef] [PubMed]

182. Zeng, J.; See, A.P.; Aziz, K.; Thiyagarajan, S.; Salih, T.; Gajula, R.P.; Armour, M.; Phallen, J.; Terezakis, S.; Kleinberg, L.; et al. Nelfinavir induces radiation sensitization in pituitary adenoma cells. Cancer Biol. Ther. 2011, 12, 657-663. [CrossRef] [PubMed]

183. Kumar, S.; Bryant, C.S.; Chamala, S.; Qazi, A.; Seward, S.M.; Pal, J.; Steffes, C.P.; Weaver, D.W.; Morris, R.; Malone, J.M.; et al. Ritonavir blocks AKT signaling, activates apoptosis and inhibits migration and invasion in ovarian cancer cells. Mol. Cancer 2009, 8, 26. [CrossRef] [PubMed]

184. Gupta, A.K.; Lee, J.H.; Wilke, W.W.; Quon, H.; Smith, G.; Maity, A.; Buatti, J.M.; Spitz, D.R. Radiation Response in Two HPV-Infected Head-and-Neck Cancer Cell Lines in Comparison to a Non-HPV-Infected Cell Line and Relationship to Signaling Through AKT. Int. J. Radiat. Oncol. 2009, 74, 928-933. [CrossRef]

185. Jiang, Z.; Pore, N.; Cerniglia, G.J.; Mick, R.; Georgescu, M.-M.; Bernhard, E.J.; Hahn, S.; Gupta, A.K.; Maity, A. Phosphatase and Tensin Homologue Deficiency in Glioblastoma Confers Resistance to Radiation and Temozolomide that Is Reversed by the Protease Inhibitor Nelfinavir. Cancer Res. 2007, 67, 4467-4473. [CrossRef]

186. Srirangam, A.; Mitra, R.; Wang, M.; Gorski, J.C.; Badve, S.S.; Baldridge, L.A.; Hamilton, J.; Kishimoto, H.; Hawes, J.; Li, L.; et al. Effects of HIV protease inhibitor ritonavir on Akt-Regulated cell proliferation in breast cancer. Clin. Cancer Res. 2006, 12, 1883-1896. [CrossRef]

187. Batchu, R.B.; Gruzdyn, O.V.; Bryant, C.S.; Qazi, A.; Kumar, S.; Chamala, S.; Kung, S.T.; Sanka, R.S.; Puttagunta, U.S.; Weaver, D.W.; et al. Ritonavir-Mediated Induction of Apoptosis in Pancreatic Cancer Occurs via the RB/E2F-1 and AKT Pathways. Pharmaceuticals 2014, 7, 46-57. [CrossRef]

188. Pasquereau, S.; Kumar, A.; Abbas, W.; Herbein, G. Counteracting Akt Activation by HIV Protease Inhibitors in Monocytes/Macrophages. Viruses 2018, 10, 190. [CrossRef] 
189. Plastaras, J.P.; Vapiwala, N.; Ahmed, M.S.; Gudonis, D.; Cerniglia, G.J.; Feldman, M.D.; Frank, I.; Gupta, A.K. Validation and toxicity of PI3K/Akt pathway inhibition by HIV protease inhibitors in humans. Cancer Biol. Ther. 2008, 7, 628-635. [CrossRef] [PubMed]

190. Ben-Romano, R.; Rudich, A.; Tirosh, A.; Potashnik, R.; Sasaoka, T.; Riesenberg, K.; Schlaeffer, F.; Bashan, N. Nelfinavir-Induced insulin resistance is associated with impaired plasma membrane recruitment of the PI3-kinase effectors AKT/PKB and PKC-Zeta. Diabetologia 2004, 47, 1107-1117. [CrossRef] [PubMed]

191. Kachko, I.; Maissel, A.; Mazor, L.; Ben-Romano, R.; Watson, R.T.; Hou, J.C.; Pessin, J.E.; Bashan, N.; Rudich, A. Postreceptoral adipocyte insulin resistance induced by nelfinavir is caused by insensitivity of PKB/Akt to phosphatidylinositol-3,4,5-trisphosphate. Endocrinology 2009, 150, 2618-2626. [CrossRef]

192. Barillari, G.; Iovane, A.; Bacigalupo, I.; Labbaye, C.; Chiozzini, C.; Sernicola, L.; Quaranta, M.T.; Falchi, M.; Sgadari, C.; Ensoli, B. The HIV protease inhibitor indinavir down-Regulates the expression of the pro-angiogenic MT1-MMP by human endothelial cells. Angiogenesis 2014, 17, 831-838. [CrossRef] [PubMed]

193. Vadlapatla, R.K.; Vadlapudi, A.D.; Pal, D.; Mukherji, M.; Mandal, A. Ritonavir inhibits HIF-1 $\alpha$-Mediated VEGF expression in retinal pigment epithelial cells in vitro. Eye 2013, 28, 93-101. [CrossRef] [PubMed]

194. Equils, O.; Shapiro, A.; Madak-Erdogan, Z.; Liu, C.; Lu, D. Human Immunodeficiency Virus Type 1 Protease Inhibitors Block Toll-Like Receptor 2 (TLR2)- and TLR4-Induced NF-кB Activation. Antimicrob. Agents Chemother. 2004, 48, 3905-3911. [CrossRef] [PubMed]

195. Zhang, G.; Zhang, X.; Huang, H.; Ji, Y.; Li, D.; Jiang, W. Saquinavir plus methylprednisolone ameliorates experimental acute lung injury. Braz. J. Med. Biol. Res. 2018, 51, 7579. [CrossRef] [PubMed]

196. Ji, Y.; Zhang, G.; Zhu, H.; Li, D.; Jiang, W. Indinavir Plus Methylprednisolone Ameliorates Experimental Acute Lung Injury In Vitro and In Vivo. Shock 2018, 49, 196-204. [CrossRef]

197. Malizia, A.P.; Cotter, E.; Chew, N.; Powderly, W.G.; Doran, P. HIV Protease Inhibitors Selectively Induce Gene Expression Alterations Associated with Reduced Calcium Deposition in Primary Human Osteoblasts. AIDS Res. Hum. Retrovir. 2007, 23, 243-250. [CrossRef]

198. Auclair, M.; Afonso, P.; Capel, E.; Caron-Debarle, M.; Capeau, J. Impact of darunavir, atazanavir and lopinavir boosted with ritonavir on cultured human endothelial cells: Beneficial effect of pravastatin. Antivir. Ther. 2014, 19, 773-782. [CrossRef]

199. Lü, J.-M.; Jiang, J.; Jamaluddin, S.; Liang, Z.; Yao, Q.; Chen, C. Ginsenoside Rb1 Blocks Ritonavir-Induced Oxidative Stress and eNOS Downregulation through Activation of Estrogen Receptor-Beta and Upregulation of SOD in Human Endothelial Cells. Int. J. Mol. Sci. 2019, 20, 294. [CrossRef]

200. Chai, H.; Yang, H.; Yan, S.; Li, M.; Lin, P.H.; Lumsden, A.B.; Yao, Q.; Chen, C. Effects of 5 HIV Protease Inhibitors on Vasomotor Function and Superoxide Anion Production in Porcine Coronary Arteries. JAIDS J. Acquir. Immune Defic. Syndr. 2005, 40, 12-19. [CrossRef]

201. Gary-Bobo, G.; Houssaini, A.; Amsellem, V.; Rideau, D.; Pacaud, P.; Perrin, A.; Brégeon, J.; Marcos, E.; Dubois-Randé, J.-L.; Sitbon, O.; et al. Effects of HIV protease inhibitors on progression of monocrotaline- and hypoxia-induced pulmonary hypertension in rats. Circulation 2010, 122, 1937-1947. [CrossRef] [PubMed]

202. Wu, Y.-J.; Lin, S.-H.; Din, Z.-H.; Su, J.-H.; Liu, C.-I. Sinulariolide Inhibits Gastric Cancer Cell Migration and Invasion through Downregulation of the EMT Process and Suppression of FAK/PI3K/AKT/mTOR and MAPKs Signaling Pathways. Mar. Drugs 2019, 17, 668. [CrossRef]

203. Su, Y.; Wan, D.; Song, W. Dryofragin inhibits the migration and invasion of human osteosarcoma U2OS cells by suppressing MMP-2/9 and elevating TIMP-1/2 through PI3K/AKT and p38 MAPK signaling pathways. Anticancer Drugs 2016, 27, 1-668. [CrossRef] [PubMed]

204. Zhao, Z.; Ma, J.; Mao, Y.; Dong, L.; Li, S.; Zhang, Y. Silence of $\alpha 1$-Antitrypsin Inhibits Migration and Proliferation of Triple Negative Breast Cancer Cells. Med. Sci. Monit. 2018, 24, 6851-6860. [CrossRef]

205. Canani, R.B.; Spagnuolo, M.I.; Cirillo, P.; Guarino, A. Ritonavir Combination Therapy Restores Intestinal Function in Children With Advanced HIV Disease. J. Acquir. Immune Defic. Syndr. 1999, 21, 307-312. [CrossRef]

206. Sgadari, C.; Barillari, G.; Toschi, E.; Carlei, D.; Bacigalupo, I.; Baccarini, S.; Palladino, C.; Leone, P.; Bugarini, R.; Malavasi, L.; et al. HIV protease inhibitors are potent anti-Angiogenic molecules and promote regression of Kaposi sarcoma. Nat. Med. 2002, 8, 225-232. [CrossRef]

207. Loizzi, V.; Del Vecchio, V.; Gargano, G.; De Liso, M.; Kardashi, A.; Naglieri, E.; Resta, L.; Cicinelli, E.; Cormio, G. Biological Pathways Involved in Tumor Angiogenesis and Bevacizumab Based Anti-Angiogenic Therapy with Special References to Ovarian Cancer. Int. J. Mol. Sci. 2017, 18, 1967. [CrossRef] [PubMed] 
208. Arbab, A.S. Activation of alternative pathways of angiogenesis and involvement of stem cells following anti-angiogenesis treatment in glioma. Histol. Histopathol. 2012, 27, 549-557. [CrossRef] [PubMed]

209. Hill, E.J.; Roberts, C.; Franklin, J.M.; Enescu, M.; West, N.; MacGregor, T.P.; Chu, K.-Y.; Boyle, L.; Blesing, C.; Wang, L.M.; et al. Clinical Trial of Oral Nelfinavir before and during Radiation Therapy for Advanced Rectal Cancer. Clin. Cancer Res. 2016, 22, 1922-1931. [CrossRef] [PubMed]

210. Wilson, J.; Fokas, E.; Dutton, S.J.; Patel, N.; Hawkins, M.A.; Eccles, C.; Chu, K.-Y.; Durrant, L.; Abraham, A.G.; Partridge, M.; et al. ARCII: A phase II trial of the HIV protease inhibitor Nelfinavir in combination with chemoradiation for locally advanced inoperable pancreatic cancer. Radiother. Oncol. 2016, 119, 306-311. [CrossRef] [PubMed]

211. Conant, M.A.; Opp, K.M.; Poretz, D.; Mills, R.G. Reduction of Kaposi's sarcoma lesions following treatment of AIDS with ritonovir. AIDS 1997, 11, 1300-1301. [CrossRef] [PubMed]

212. Lebbé, C.; Blum, L.; Pellet, C.; Blanchard, G.; Verola, O.; Morel, P.; Danne, O.; Calvo, F. Clinical and biological impact of antiretroviral therapy with protease inhibitors on HIV-Related Kaposi's sarcoma. AIDS 1998, 12, F45-F49. [CrossRef]

213. Ahluwalia, M.S.; Patton, C.; Stevens, G.; Tekautz, T.; Angelov, L.; Vogelbaum, M.A.; Weil, R.J.; Chao, S.; Elson, P.; Suh, J.H.; et al. Phase II trial of ritonavir/lopinavir in patients with progressive or recurrent high-Grade gliomas. J. Neurooncol. 2010, 102, 317-321. [CrossRef] [PubMed]

214. Hoover, A.C.; Milhem, M.; Anderson, C.; Sun, W.; Smith, B.J.; Hoffman, H.T.; Buatti, J.M. Efficacy of nelfinavir as monotherapy in refractory adenoid cystic carcinoma: Results of a phase II clinical trial. Head Neck 2014, 37, 722-726. [CrossRef] [PubMed]

215. Wang, Y.; Lv, Z.; Chu, Y. HIV protease inhibitors: A review of molecular selectivity and toxicity. HIV AIDS 2015, 7, 95-104. [CrossRef] [PubMed]

216. Zhang, J.; Yu, H.; Sun, F.-Y.; Li, J.; Li, D.-M.; Sun, C.-H. Effects of lamivudine on cell proliferation of liver cancer and expressions of HBsAg, HBeAg, and MMP-9 in patients. Eur. Rev. Med. Pharmacol. Sci. 2019, 23, 9093-9098. [PubMed]

217. Song, L.; Ding, S.; Ge, Z.; Zhu, X.; Qiu, C.; Wang, Y.; Lai, E.; Yang, W.; Sun, Y.; Chow, S.A.; et al. Nucleoside/nucleotide reverse transcriptase inhibitors attenuate angiogenesis and lymphangiogenesis by impairing receptor tyrosine kinases signalling in endothelial cells. Br. J. Pharmacol. 2017, 175, 1241-1259. [CrossRef]

218. Wang, X.; Chai, H.; Lin, P.H.; Yao, Q.; Chen, C. Roles and Mechanisms of Human Immunodeficiency Virus Protease Inhibitor Ritonavir and Other Anti-Human Immunodeficiency Virus Drugs in Endothelial Dysfunction of Porcine Pulmonary Arteries and Human Pulmonary Artery Endothelial Cells. Am. J. Pathol. 2009, 174, 771-781. [CrossRef]

219. Jamaluddin, S.; Lin, P.H.; Yao, Q.; Chen, C. Non-Nucleoside reverse transcriptase inhibitor efavirenz increases monolayer permeability of human coronary artery endothelial cells. Atherosclerosis 2009, 208, 104-111. [CrossRef]

220. Matłosz, B.; Kowalska, J.D.; Bąkowska, E.; Firlag-Burkacka, E.F.-B.; Vassilenko, A.; Horban, A. Discontinuation of tenofovir due to nephrotoxicity: Insight into 12 years of clinical practice. Przegl. Epidemiol. 2019, 73, 249-255. [CrossRef]

221. Quercia, R.; Perno, C.-F.; Koteff, J.; Moore, K.; McCoig, C.; Clair, M.S.; Kuritzkes, D. Twenty-Five Years of Lamivudine. J. Acquir. Immune Defic. Syndr. 2018, 78, 125-135. [CrossRef] [PubMed]

222. De Clercq, E. Mozobil (Plerixafor, AMD3100), 10 years after its approval by the US Food and Drug Administration. Antivir. Chem. Chemother. 2019, 27. [CrossRef] [PubMed]

223. Chinni, S.R.; Sivalogan, S.; Dong, Z.; Filho, J.C.T.; Deng, X.; Bonfil, R.D.; Cher, M.L. CXCL12/CXCR4 signaling activates Akt-1 and MMP-9 expression in prostate cancer cells: The role of bone microenvironment-Associated CXCL12. Prostate 2006, 66, 32-48. [CrossRef] [PubMed]

224. Ordóñez, A.M.; Seoane, S.; Cabezas, P.; Eiro, N.; Lago, J.J.S.; Macia, M.; García-Caballero, T.; Gonzalez, L.O.; Sánchez, L.; Vizoso, F.; et al. Breast cancer metastasis to liver and lung is facilitated by Pit-1-CXCL12-CXCR4 axis. Oncogene 2018, 37, 1430-1444. [CrossRef]

225. Sleightholm, R.L.; Neilsen, B.K.; Li, J.; Steele, M.M.; Singh, R.K.; Hollingsworth, M.A.; Oupicky, D. Emerging roles of the CXCL12/CXCR4 axis in pancreatic cancer progression and therapy. Pharmacol. Ther. 2017, 179, 158-170. [CrossRef] 
226. Wang, X.; Cao, Y.; Zhang, S.; Chen, Z.; Fan, L.; Shen, X.; Zhou, S.; Chen, D. Stem cell autocrine CXCL12/CXCR4 stimulates invasion and metastasis of esophageal cancer. Oncotarget 2017, 8, 36149-36160. [CrossRef]

227. Mao, T.L.; Fan, K.F.; Liu, C.L. Targeting the CXCR4/CXCL12 axis in treating epithelial ovarian cancer. Gene Ther. 2017, 24, 621-629. [CrossRef]

228. Stanisavljević, L.; Aßmus, J.; Storli, K.E.; Leh, S.; Dahl, O.; Myklebust, M.P. CXCR4, CXCL12 and the relative CXCL12-CXCR4 expression as prognostic factors in colon cancer. Tumor Biol. 2015, 37, 7441-7452. [CrossRef]

229. Gravina, G.L.; Mancini, A.; Muzi, P.; Ventura, L.; Biordi, L.; Ricevuto, E.; Pompili, S.; Mattei, C.; Di Cesare, E.; Jannini, E.A.; et al. CXCR4 pharmacogical inhibition reduces bone and soft tissue metastatic burden by affecting tumor growth and tumorigenic potential in prostate cancer preclinical models. Prostate 2015, 75, 1227-1246. [CrossRef]

230. Werner, T.A.; Forster, C.M.; Dizdar, L.; Verde, P.E.; Raba, K.; Schott, M.; Knoefel, W.T.; Krieg, A. CXCR4/CXCR7/CXCL12-Axis in Follicular Thyroid Carcinoma. J. Cancer 2018, 9, 929-940. [CrossRef]

231. Chaudary, N.; Pintilie, M.; Jelveh, S.; Lindsay, P.; Hill, R.P.; Milosevic, M. Plerixafor Improves Primary Tumor Response and Reduces Metastases in Cervical Cancer Treated with Radio-Chemotherapy. Clin. Cancer Res. 2016, 23, 1242-1249. [CrossRef] [PubMed]

232. Rios, A.; Hsu, S.H.; Blanco, A.; Buryanek, J.; Day, A.L.; McGuire, M.F.; Brown, R.E. Durable response of glioblastoma to adjuvant therapy consisting of temozolomide and a weekly dose of AMD3100 (plerixafor), a CXCR4 inhibitor, together with lapatinib, metformin and niacinamide. Oncoscience 2016, 3, 156-163. [CrossRef] [PubMed]

233. Janku, F.; Yap, T.A.; Meric-Bernstam, F. Targeting the PI3K pathway in cancer: Are we making headway? Nat. Rev. Clin. Oncol. 2018, 15, 273-291. [CrossRef] [PubMed]

234. Driessen, C.; Müller, R.; Novak, U.; Cantoni, N.; Betticher, D.; Mach, N.; Rüfer, A.; Mey, U.; Samaras, P.; Ribi, K.; et al. Promising activity of nelfinavir-Bortezomib-Dexamethasone in proteasome inhibitor-refractory multiple myeloma. Blood 2018, 132, 2097-2100. [CrossRef]

235. De Weger, V.A.; Stuurman, F.E.; Hendrikx, J.J.; Moes, J.J.; Sawicki, E.; Huitema, A.D.R.; Nuijen, B.; Thijssen, B.; Rosing, H.; Keessen, M.; et al. A dose-Escalation study of bi-Daily once weekly oral docetaxel either as ModraDoc001 or ModraDoc006 combined with ritonavir. Eur. J. Cancer 2017, 86, 217-225. [CrossRef]

236. Tołoczko-Iwaniuk, N.; Dziemiańczyk-Pakieła, D.; Nowaszewska, B.K.; Celińska-Janowicz, K.; Miltyk, W. Celecoxib in Cancer Therapy and Prevention-Review. Curr. Drug Targets 2019, 20, 302-315. [CrossRef]

237. Overman, M.J.; Lonardi, S.; Wong, K.Y.M.; Lenz, H.-J.; Gelsomino, F.; Aglietta, M.; Morse, M.A.; Van Cutsem, E.; McDermott, R.; Hill, A.; et al. Durable Clinical Benefit With Nivolumab Plus Ipilimumab in DNA Mismatch Repair-Deficient/Microsatellite Instability-High Metastatic Colorectal Cancer. J. Clin. Oncol. 2018, 36, 773-779. [CrossRef]

(C) 2020 by the author. Licensee MDPI, Basel, Switzerland. This article is an open access article distributed under the terms and conditions of the Creative Commons Attribution (CC BY) license (http://creativecommons.org/licenses/by/4.0/). 